\title{
RUDOLF BERLINER I JEGO WKŁAD W ROZUMIENIE CHRZEŚCIJAŃSKIEGO OBRAZU1
}

Życie uczonych takich jak Rudolf Berliner, upływające w monotonnym rytmie mozolnych prac i badań, wielu zdawać się może nieciekawe. Stąd na kolejnych stronach biografia Berlinera przedstawiona zostanie tylko pobieżnie; zamiast tego skoncentrujemy się na wprowadzeniu do jego myśli. Ale trzeba zwrócić uwagę przynajmniej na te okoliczności, które - na ile możemy o tym sądzić - odcisnęły piętno na jego osobowości, to jest przede wszystkim na wydarzenia od roku 1933, które, zagrażając życiu, prawdziwie wstrząsnęły jego egzystencją: od aresztowania w 1933 do emigracji w 1939.

\section{POCHODZENIE I EDUKACJA²}

Rudolf Berliner pochodził z żydowskiej rodziny, której historia pozwala prześledzić się zaledwie trzy pokolenia wstecz. Pradziad Berlinera, Aron (1795-1859), zachęcony być może wczesną emancypacją Żydów w Prusach, osiedlił się na Śląsku; w dokumentach rodzinnych wspominany jest jako posiadacz ziemski. Dziad Wilhelm (1822-1881) miał już własny bank i był założycielem kilku fabryk w dolnośląskiej Oławie, stracił

${ }^{1}$ R. Suckale, Rudolf Berliner und sein Beitrag zum Verständnis des christlichen Bildes, (w:) Rudolf Berliner (1886-1967), „The Freedom of Medieval Art” und andere Studien zum christlichen Bild, hrsg. v. Robert Suckale, Berlin: Lukas Verlag 2003, s. 9-21.

2 Większość informacji czerpię z dokumentów, które powierzył mi młodszy syn Rudolfa Berlinera Christopher Bever, a które ja z kolei mam zamiar przekazać archiwum Germańskiego Muzeum Narodowego (Germanisches Nationalmuseum) w Norymberdze. Interesujący był także protokół z postępowania promocyjnego z załączonym doń odręcznym życiorysem, którego znajomość, dzięki pośrednictwu Gerharda Schmidta, zawdzięczam archiwum uniwersyteckiemu w Wiedniu. 
wszakże bank i dwie fabryki w wielkim krachu roku 1878. Z żoną Rosalie z domu Leipziger mieli dziesięcioro dzieci. Najstarszy syn Theodor (18511915), ojciec Rudolfa Berlinera, przejął najpierw ocalałą fabrykę w Oławie, potem jednak przeniósł się do Berlina, gdzie założył w 1898 roku Deutsche Grammophone AG, spółkę córkę British Grammophone Co. Ltd. Na dalszą życiową ścieżkę Theodora wpłynęła w dużym stopniu błyskotliwa kariera jego młodszego brata Alfreda (1861-1943) w firmie Siemens. W roku 1888, jako młody fizyk, podjął Alfred zatrudnienie w firmie Siemens \& Halske. Pracował dla niej w Stanach Zjednoczonych, a w 1896, w uznaniu zaangażowania i talentów organizacyjnych, przejął kierownictwo działu „Oświetlenie i energia” (Beleuchtung und Kraft). Był najbliższym doradcą Wernera v. Siemensa podczas negocjacji w sprawie fuzji z firmą Schuckert. Od 1901 roku zasiadał w zarządzie firmy Siemens-Schuckertwerke, pełniąc w latach 1903-1912 funkcję prezesa; potem jednak został przesunięty do rady nadzorczej Siemens \& Halske ${ }^{3}$. Theodor został w 1904 roku prokurentem w Siemens-Schuckertwerke, zaś w 1908 dyrektorem zarządzającym w Siemens \& Halske. W roku 1912, najpewniej w związku $\mathrm{z}$ nieporozumieniami pomiędzy młodszym bratem a kierownictwem firmy, przeniósł się do przejętej wówczas przez Siemensa firmy Bergmann. Później został dyrektorem fabryki akumulatorów, powstałej w wyniku wspólnej inicjatywy Siemensa i AEC, kierował nią jednak po części z Berlina4.

Theodor, podobnie jak większość członków rodziny w jego pokoleniu, odwrócił się od wiary ojców i przyjął protestantyzm 5 . Ostatecznie było to warunkiem dopuszczenia do „wyższych kręgów” cesarstwa ${ }^{6}$. Miał ze swą żoną Phillipine Wollner, córką lekarza praktykującego we Wrocławiu i potem w Karlsbadzie, dwóch synów: Wilhelma (ur. 1882, poległy w 1914 pod Metz) i Paula Rudolfa (ur. 14 kwietnia 1886 w Oławie). Ich edukację powierzono po części domowemu nauczycielowi, po części francuskiej „Mademoiselle”, stąd wczesna znajomość francuskiego przez dzieci. W 1899 roku rodzina przeniosła się do Berlina; Rudolf podjął naukę

${ }^{3}$ Dr Nägler umożliwił mi uprzejmie dostęp do archiwum firmy Siemens. Na temat działalności obu braci Berlinerów zob.: G. Siemens, Der Weg der Elektrotechnik. Geschichte des Hauses Siemens, 2 Bd., Freiburg/Br. u. München 1961, zwł. t. 2, s. 77 i n. oraz s. 126; W. Feldenkirchen, Siemens 1918-1945, München u. Zürich 1995, zwł. s. 348 i 533, przyp. 42.

${ }^{4}$ U Georga Siemensa (jak w przyp. 2), t. 2, s. 9 i n. myli się obu braci.

5 Informacja podana przez Angelo Stafanucciego w nekrologu Rudolfa Berlinera, jakoby rodzina Berlinerów miała pochodzenie rabiniczne, wydaje się nieprawdziwa.

6 Theodor Berliner był członkiem Cesarskiego Jachtklubu w Kilonii i na swych jachtach brał udział w regatach. Niektórzy członkowie rodziny należeli nawet do Związku Wszechniemieckiego (Alldeutscher Verband), który można zaklasyfikować jako ultrakonserwatywny. 
w gimnazjum w Joachmistahl i tam też zdał egzamin maturalny w 1904 roku, sześć lat przed Panofskym.

Rudolf Berliner wywodził się zatem z kręgów zamożnego mieszczaństwa, pozostając pod wpływem, z jednej strony, rodzinnego zmysłu przedsiębiorczości, oraz, z drugiej strony, pruskich ideałów, wysoko cenionych w tej grupie społecznej: bezwzględnej obowiązkowości, służby na rzecz państwa i wspólnoty, żołnierskiej dyscypliny. Wszyscy mężczyźni w rodzinie Berlinerów należeli do tzw. ,jednoroczniaków” (Einjährige), tj. służyli ponad przewidziany czas $\mathrm{w}$ armii, uzyskując $\mathrm{w}$ ten sposób stopnie oficerów rezerwy: Theodor Berliner wymieniany jest w aktach Siemensa jako porucznik rezerwy. Rudolf pozostawał w czynnej służbie od pierwszego do ostatniego dnia pierwszej wojny światowej, służąc w stopniu podporucznika w Trzecim Pułku Grenadierów Gwardii im. Królowej Elżbiety - w pierwszym roku wojny głównie jako dowódca jednostki przeznaczonej do zbierania z pola bitwy rannych i rozproszonych żołnierzy.

Rodzina Berlinerów regularnie spędzała wakacje letnie w okolicach Berchtesgaden [w Górnej Bawarii]. Tam, przez przyjaciela z dzieciństwa Wolfa Bevera, poznał Rudolf swoją przyszłą żonę Marię Karolinę Charlottę Bever; urodzona w 1881 roku w Szczecinie (zm. 14 kwietnia 1981 r., a więc $\mathrm{w}$ wieku stu lat), w starej rodzinie fabrykancko-oficerskiej, była właścicielką domu zwanego Schneewinkellehen, położonego u stóp Watzmanna w Schönau-Königssee ${ }^{7}$. Tam też nawiązał Berliner kontakty ze środowiskiem przyjaciół skupionych wokół Marie Andree-Eysn i Rudolfa Krissa, którzy prowadzili badania nad religijnością ludową .

Rudolf Berliner był pierwszym uczonym humanistą w rodzinie. W latach 1905-1909 studiował głównie nowszą historię sztuki i archeologię klasyczną w Berlinie, Heidelbergu i Wiedniu. Początkowo chciał z pewnością zostać orientalistą. W 1913 r. odbył podróż do wschodniej Anatolii w towarzystwie swojego szwagra, wspomnianego już Wolfa Bevera, której owocem była wspólna publikacja. Studia nad armeńskimi kościołami i meczetem w Diyarbakir (nr 22-24), podobnie jak recenzje i publikacje (nr 11, 92, 93, 102, 103) dowodzą jego zainteresowania Wschodem. Przez

7 Według Christophera Bevera (jak w przyp. 1) posiadłość ta stanowiła spadek po jego babce ze strony matki, pierwotnie należała więc do rodziny Bever.

8 Marie Andree-Eysn była żoną słynnego geografa i antropologa kultury Richarda Andree (1835-1912) i zaadoptowała jego metodykę do studiów nad religijnością ludową; por. H. Nikitsch, Marie Andree-Eysn. Quellenfunde zur Biographie, „Jahrbuch für Volkskunde" 24, 2001, s. 7-26; idem, Eine Volkskundlerin aus Salzburg. Marie Andree-Eysn (1847-1929), „Salzburger Volkskultur” 25, 2001, s. 42-50. Lektura jej pism, choćby Volkskundliches aus dem bayrisch-österreichischen Alpengebiet, Braunschweig 1910, pozwala zrozumieć, dlaczego powaga, z jaką traktowała wiarę ludową wraz z jej potężnie oddziałującymi obrazami, zrobiła takie wrażenie na Berlinerze. 
całe życie poświęcał uwagę temu kręgowi kulturowemu, od osiedlenia się w Waszyngtonie w 1958 roku, jako doradca Textile Museum, głównie tkaninom koptyjskim.

Możemy jedynie domniemywać, w jakim stopniu konflikt z promotorem rozprawy doktorskiej Josefem Strzygowskim odstręczył go od orientalistyki. Strzygowski był jednym z pierwszych, którzy podnosili znaczenie architektury armeńskiej i w ogóle kultur orientalnych dla Zachodu. Jednakże już wówczas myśl jego nosiła znamię sekciarstwa i politycznego nonsensu; później stał się jednym z najbardziej pokrętnych ideologów nazistowskich. W dysertacji doktorskiej Berliner przywołuje jego nazwisko tylko raz, i to krytycznie, podczas gdy z uznaniem, a wręcz apologetycznie, odnosi się po wielekroć do Aloysa Riegla, który - nienawidzony przez Strzygowskiego - wywarł na nim wielkie wrażenie. O książce Riegla Spätrömische Kunstindustrie, wydanej w Wiedniu w 1901 r., pisał: „Jestem temu dziełu zobowiązany niczym nauczycielowi”. Mówiąc krótko: jak wynika z protokołu rigorosum, za sprawą Josefa Strzygowskiego i Maxa Dvořáka Berliner oblał w dniu 27 lutego 1910 r. ustny egzamin doktorski; na poprawce w dniu 16 lipca 1910 r. również wystarczyło tylko na ocenę „dostateczną” (genügend)10. Bezkompromisowa szczerość i wstręt wobec wszelkiego lizusostwa od początku stanowiły rys osobowości tego uczonego.

9 E. Frodl-Kraft, Aporie und der Versuch ihrer Deutung. Josef Strzygowski und Julius v. Schlosser, „Wiener Jahrbuch für Kunstgeschichte” 42, 1989, s. 7-52; o radykalnej krytyce studium Strzygowskiego Wschód $i$ Rzym, zawartej w dysertacji Berlinera - s. 31 i n.; cytat dotyczący Riegla - s. 21, przyp. 2. Wpływ Riegla uwidacznia się choćby w następującym zdaniu (s. 26): „(...) także niepokój poczucia stylu, w którym element stylu rysunkowego miesza się z malarskim (...) Odgraniczenia mają charakter płaszczyznowy, dążąc do konstrukcyjnej jasności”, albo innym (s. 27): „Faza przejściowa między stylem malarsko-konstruktywnym a rysunkowo-barwnym"; zob. także s. 29. Potem wypowiadał się Berliner krytycznie także o innych przedstawicielach szkoły wiedeńskiej; o Dvořáku (m.in. V, s. 281 i XIII, s. 86) oraz Juliusa von Schlossera, Die Kunst- und Wunderkammer des Spätrenaissance, Leipzig 1908 (nr 39, s. 328, przyp. 9): „Szczerość wymaga otwartego wyznania, że zarówno zasadnicze ujęcie, jak i szczegóły (...) - przy całym szacunku - uważam za chybione; już sam tytuł jest błędny. Ten sąd dotyczy także tych, którzy idą jego śladem”. Jego znakomicie uargumentowana polemika pozostała jednak niemal zupełnie nieznana. (Zob. także tutaj s. 235.)

10 Przebieg studiów jest doskonale udokumentowany w curriculum vitae: od Wielkanocy 1905 dwa semestry w Berlinie; lato 1906 w Heidelbergu; następne dwa semestry znów w Berlinie; zima 1907/1908 w Wiedniu; potem ponownie rok w Berlinie, w tym czasie katedrę historii sztuki obejmował Heinrich Wölfflin. Latem 1908 przedsięwziął Berliner podróż studyjną do Paryża (zob. niżej). Zob. także: U. Wendland, Biographisches Handbuch deutschsprachiger Kunsthistoriker im Exil. Leben und Werk der unter dem Nationalsozialismus verfolgten und vertriebenen Wissenschaftler, T. I: A-K, München 1999, s. 42-45. 
W swojej dysertacji, monografii najsłynniejszego bizantyńskiego psałterza „arystokratycznej redakcji”, kodeksu par. gr. 139 z paryskiej Bibliotèque Nationale ${ }^{11}$, usiłował Berliner dowieść, że psałterz jest młodszy niż dotąd sądzono powszechnie (za późniejszym datowaniem opowiadał się również jego promotor). Precyzyjne obserwacje odnośnie do techniki malarskiej, szczegółowy wywód ikonograficzny, rozważania nad stosunkiem ilustracji w zwoju i kodeksie, przede wszystkim jednak metodologicznie wzorcowa i subtelna analiza walorów artystycznych stanowią wyróżniki tej pracy. Zacytujmy zawarte $\mathrm{w}$ tym pierwszym dziele uwagi na temat personifikacji (s. 30):

Gdzie tylko pojawiają się, niosą z sobą powiew boskości (...), depozytariuszki wiecznej zasady - i tak powstaje wrażenie obrazu kultowego, apoteozy (...). Ale z egzaltowanej, prawie że surowej powagi, która panuje w obrazach, z prostoty i rzetelności opowieści, wynika jasno: celem była bezpośrednia jasność, zrozumiałość treści. W ilustrowaniu określonej duchowej treści sztuka poczyna widzieć swe najwyższe zadanie. Zagubieniu ulega artystyczne zainteresowanie figurą, która zyskuje znaczenie jedynie jako nośnik działania, jako naczynie duchowej treści (...).

Już na tym wczesnym etapie dochodzi zatem do głosu zasadnicze przekonanie Berlinera: że sztuka chrześcijańska, łącznie z jej formą, może być rozumiana wyłącznie jako sztuka przedstawiająca. To odróżnia jego postępowanie od tradycyjnych badań ikonograficznych, w których treści wyczytuje się na ogół z tekstów, nie biorąc pod uwagę, że sztuka, aż po najmniejsze szczegóły, determinowana jest przez zadanie przedstawiania. Jemu zaś już wówczas chodziło o uchwycenie tego, co - w porównaniu do antyku - zasadniczo odrębne w obrazie chrześcijańskim.

Nie wiadomo, w jakich okolicznościach Berliner został powołany do Bayerisches Nationalmuseum, najważniejszej wówczas monachijskiej instytucji badawczej w zakresie historii sztuki. Źródła wskazują, że zatrudniony był tam jako pracownik naukowy od 1 maja 1912 do 31 grudnia 1919 roku. Potem krótko, od 1 stycznia do 30 października 1920 roku, pracował jako asystent naukowy w Zbiorach Graficznych, następnie został konserwatorem, a wreszcie głównym konserwatorem w Nationalmuseum, która to funkcja wiązała się z uzyskaniem tytułu profesorskiego.

11 Wstęp, a także rozproszone w tekście uwagi, zdają się świadczyć, że miał to być fragment większego studium, nad którym pracował w paryskiej Bibliotèque Nationale w 1908 i pierwszej połowie 1909 roku; potem Henri Omont zakazał mu dalszego korzystania z rękopisu. Jako adres zamieszkania podał wówczas Kronprinzalle 2 w Berlinie-Grunewaldzie, jednej z najelegantszych dzielnic miasta, potem Kurfürstendamm 213. Na temat rękopisu ostatnio: A. Cutler, The Aristocratic Psalters in Byzantium, Paris 1984 (Bibliotèque des Cahiers Archéologiques 13). 
W jego rękach spoczywała redakcja „Münchener Jahrbuch der bildenden Kunst”. Utrzymywał przyjacielskie stosunki z kolegami z muzeum, Georgiem Lillem, Philippem Marią Halmem, Hansem Buchheitem i potem Theodorem Müllerem, a także $\mathrm{z}$ dyrektorem Muzeum Teatru (Theatermuseum), Franzem Rappem ${ }^{12}$.

$\mathrm{W}$ zgodzie $\mathrm{z}$ wpojonym mu poczuciem służby i obowiązku, Berliner gromadził eksponaty wyłącznie dla muzeum, nigdy dla siebie, zawsze $\mathrm{z}$ wielkim zaangażowaniem i znakomitym wyczuciem ${ }^{13}$. Odczuwał wstręt wobec komercyjnego wykorzystania znawstwa i bogacenia się na podejrzanej działalności eksperckiej - przeciwnie, zwalczał ją z determinacją. Jego opracowania zbiorów uznać trzeba za wzorcowe; zwłaszcza w katalogu rzeźby w kości słoniowej (nr 33) ustanowił nowe standardy, przewyższające prace Vöge i Goldschmidta. Nadto zmienił aranżację ekspozycji barokowej plastyki w kości słoniowej i innych działów kolekcji, a także publikował na ten temat ( $\mathrm{nr} 29,30)$. Wiele uwagi poświęcał drobnej plastyce, której zbiór wzbogacił zakupem m.in. grupy Herkulesa z Anteuszem Petera Vischera. Poświęcone tej rzeźbie publikacje (nr 34, 46) wykorzystał do podjęcia problemu oceny i podziału pracy w wieloosobowym warsztacie norymberskiego odlewnika. Powszechnej niechęci wobec atrybucji opartych na analizie stylistycznej - która to metoda wciąż jeszcze stanowi najpewniejszą drogę do poznania praktyki warsztatowej i artystycznej oryginalności w obliczu braku źródeł pisanych - przeciwstawić można jego uwagi odnośnie do kontrowersji wokół nagrobka św. Sebalda:

Jestem przekonany, że Meller miał zasadniczo właściwy ogląd i prawidłowo rozróżnił ręce [poszczególnych artystów zaangażowanych w prace nad pomnikiem, M.M.]. Że matematycznej pewności nie udaje się jednak osiągnąć nigdy, że chodzić musi zawsze li tylko o hipotezy - jest jasne. Zawsze może się zdarzyć, że przy jednym (...) dziele pracowało sześciu czy więcej artystów, którzy przede wszystkim przez „przetworzenie” („Ausbereitung”) zafałszowali właściwy sobie

12 Razem z Marią Philippem Halmem napisał książkę o Hallesches Heiltum, zadedykowaną Marcowi Rosenbergowi; pamięci Halma poświęcił nr IV, pamięci jego syna Piotra - nr XIII; artykuł nr 1 zadedykował Marie Andree-Eysn, jej pamięci poza tym nr III; Hansowi Buchheitowi zadedykował Ornamentale Vorlage-Blätter (nr 30), jego żonie książkę o bożonarodzeniowych szopkach, Theodorowi Müllerowi artykuły nr X i 85, Martinowi Weinbergerowi - nr XII. Na temat Rappa zob.: U. Wendland, op. cit., II, s. 535-537; na temat Weinbergera: ibidem, s. 724-727; na temat podziwianego przez Berlinera Hansa Tietze: ibidem, s. 689-699. Rapp był mu bliski już choćby ze względu na temat dysertacji: było to studium o związkach teatru kościelnego ze sztukami przedstawiającymi w późnym średniowieczu, Kallmünz 1936.

13 Według Kriss-Rettenbecka liczba eksponatów pozyskanych przez Berlinera była bardzo duża, zwłaszcza w dziale sztuki ludowej. Zakupy odzwierciedlały jego zainteresowania badawcze. Por. idem, Bilder und Zeichen religiösen Volksglaubens, München 1963. 
charakter. Do tego jeszcze wielokrotne użycie pozostających do dyspozycji modeli. Ponieważ stoimy wobec nieprzeniknionych mroków organizacji warsztatowej, w wielu kwestiach zasadniczych nie możemy domagać się niczego ponad najwyższe prawdopodobieństwo. Mellerowi udało się wszakże w niektórych dziełach stwierdzić występowanie określonych cech charakterystycznych, przypisać je do danego okresu i w ten sposób, konfrontując z datami życia artystów, z dużym prawdopodobieństwem odnieść je do działalności poszczególnych członków rodziny. Nie wydaje mi się, by można było przeciw takiemu postępowaniu - zachowując świadomość jego hipotetycznego charakteru - wysuwać jakiekolwiek zarzuty, podobnie jak nie czynimy zarzutów paleografowi, gdy usiłuje rozpoznać poszczególne ręce w obrębie danej szkoły pisarskiej. Pytanie o podział pracy zostało więc postawione, ostatecznej odpowiedzi na nie można by jednak udzielić jedynie wówczas, gdyby dysponowano najskrupulatniej prowadzonymi w warsztacie księgami zatrudnienia. A zatem: albo trzeba zrezygnować zupełnie, albo próbować odtworzyć na drodze analizy cech stylistycznych - i z uwzględnieniem okoliczności zewnętrznych - „możliwy” obraz. Jeśli ten nie jest wewnętrznie sprzeczny, zachowuje ważność - hipotetyczną ważność - do czasu, gdy przeciwstawiony mu zostanie inny, bardziej przekonujący, ale wciąż hipotetyczny obraz. Ostrożność jest wskazana w przypadku każdego osiągnięcia nauk humanistycznych, ostrożność, która znaczy tu tyle, co sprzeciw wobec prezentowania jakiegoś osiągnięcia jako obowiązującego po wsze czasy i dla wszystkich punktów widzenia. Pewność jest niemożliwa. Ale przecież przekonująca hipoteza różna jest od mitu, który, dowolnie obchodząc się z obiektywnymi świadectwami, przedstawia wydarzenia tak, jak chciałby, by przebiegały ${ }^{14}$.

Oprócz tego ukończył Berliner książkę Ornamentale Vorlage-Blätter des 15.-18. Jahrhunderts [„Wzorniki ornamentów XV-XVIII w.”] (nr 30), odznaczającą się jasnością i zwięzłością opisu i analizy oraz wyjątkowym $\mathrm{w}$ tych wzburzonych nacjonalistycznie latach suwerennym internacjonalizmem. Lapidarnie stwierdza: „Należy (...) do istoty grafiki to, że jest ona ze wszystkich sztuk najbardziej międzynarodowa”. Jemu przede wszystkim zawdzięczamy rozpoznanie oddziaływania dekoracji pałacu w Fontainbleau na dzieje europejskiej ornamentyki, a także roli artystów, takich jak Ducerceau czy Bérain ${ }^{15}$. Książka ta stanowi zarazem

${ }^{14} \mathrm{Nr}$ 46, s. 139; Berliner powołuje się na: S. Meller, Peter Vischer der Ältere und seine Werkstatt, Leipzig 1925; na stronie 135 czytamy: „Kto pod pojęciem pisarstwa historycznego rozumie próbę wyobrażeniowej rekonstrukcji w oparciu o pozostawione oznaki życia, ułożone w sensowne związki...” (...).

15 OV, s. 116; na temat Rosso w Fontainebleau s. 148 i n., na temat Ducerceau s. 159 i n., na temat Béraina s. 166 i n. Wznowienie książki, zmienionej samowolnie przez Gerharda Eggera i poszerzonej o zupełnie inaczej opracowaną część dotyczącą XIX wieku, zostało zrecenzowane przez: Carstena P. Warncke (w:) „Panatheon” 41, 1983, s. 86; Petera Vergo (w:) „Burlington Magazine” 125, 1983, s. 431-432; Günthera Irmschera (w:) „Zeitschrift für Kunstgeschichte” 47, 1984, s. 137-141; Yvonne Hakkenbroch (w:) „Kunstchro- 
ostatni głos w dyskusji z Aloysem Rieglem, nie będąc bynajmniej, jak to widać wyraźnie we wtrąconych tu i ówdzie krytycznych uwagach, a bardziej jeszcze w koncepcji dzieła, kontynuacją jego sposobu myślenia. Berliner, bardziej trzeźwo patrzący niż w czasach doktoratu, musiał nabrać coraz większego sceptycyzmu wobec niejasnych, uogólniających teorii Riegla, choćby wobec pojęcia „woli artystycznej” czy próby wyjaśnienia dziejów sztuki jako następujących po sobie okresów dominacji wartości optycznych i haptycznych. Stanął tym samym w opozycji wobec tych aspektów myśli Riegla, które wtenczas przez wzgląd na modę i z przyczyn ideologicznych właśnie faworyzowano ${ }^{16}$. Jego stosunek do szkoły wiedeńskiej uwidacznia się m.in. w tym, że był w przyjaźni z Hansem Tietze i Kurtem Rathe, w gwałtownym sporze zaś - z Ernstem Gombrichem; Dvořáka, Schlossera i Riegla wspomina często, choć krytycznie, Strzygowskiego i Seldmayra - nigdy ${ }^{17}$.

Poważne studia nad ornamentyką nie przystawały do programowo purystycznych, wrogich ornamentowi lat dwudziestych, podobnie jak wymagająca wyrzeczeń, żmudna praca nad opracowaniem podręcznika. Należy się jednak wystrzegać przed postrzeganiem Berlinera jako outsidera albo umysłu zwróconego ku przeszłości. Że nie był wrogiem moderny świadczy choćby fakt, że w zasadzie to on był inicjatorem powołania tak zwanej Nowej Kolekcji w Bayerisches Nationalmuseum. Do studiów nad ornamentyką pchnęło go przekonanie, że moderna niewłaściwie pojęła i oceniła sztukę i kulturę po wielkiej rewolucji roku 1789, czego przejawem, obok deprecjacji tzw. sztuki użytkowej, było właśnie zaniedbanie, więcej: pogarda wobec ornamentu. Instruktywny tekst, nazwany w typo-

nik” 38, 1985, s. 108-112. Pisze ona [Hakkenbroch] o Berlinerze (s. 109): „His way of explaining fluctuations of style in various countries, whether of regional or international significance, remains unsurpassed in clarity, brevity and, above all, in modesty. Where else can one find such pertinent descriptions (...)".

16 E. Panofsky, Der Begriff des Kunstwollens, „Zeitschrift für Ästhetik und allgemeine Kunstwissenschaft" 14, 1920, s. 321-339 (wielokrotnie przedrukowywane, także po angielsku); H. Seldmayr, Die Quintessenz der Lehren Riegls, (w:) Alois Riegl: Gesammelte Aufsätze, Augsburg 1929, s. XI-XXXIV (recenzja Hansa Jantzena w „Kritische Berichte” 1930/ 1931, szp. 65-73); O. Pächt, Alois Riegl, ponownie wydany (w:) tegoż, Methodisches zur Kunsthistorischen Praxis, München 1977, s. 141-152; W. Sauerländer, Alois Riegl und die Entstehung der autonomen Kunstgeschichte am Fin de Siècle, (w:) R. Bauer i in. (red.), Fin de Siècle. Zu Literatur und Kunst der Jahrhundertwende, Frankfurt/M. 1977, s. 125139. Krytyka Riegla przez N. Huse, Denkmalpflege. Deutsche Texte aus drei Jahrhunderten, München 1984, zwł. s. 124-149.

17 Wiele przychylnych słów znajdował dla jezuity Josefa Brauna (np. nr 48) i Aloysa Grillmaiera (nr XI), sceptycznie wypowiadał się natomiast o metodzie Günthera Bandmanna, a bardziej jeszcze Erwina Panofsky'ego. 
wej dla Berlinera manierze nazbyt skromnie „Słowem towarzyszącym” (Begleitwort), rozpoczyna się tak:

Historyczno-artystyczna epoka, która - by obrać sformułowanie pozytywne - ma odwagę odrzucić prymat ugruntowanej na wyższym życiu duchowym woli stylu i zastąpić go zakorzenioną w idealizmie, materializmie, technice, ekonomii i tym podobnych przyczynach niższego szczebla anarchią form obrazowych, epoka, w której nawet modzie, wyjąwszy wąską dziedzinę jej panowania w ubiorze, nie udaje się narzucić znajdującego w niej ostatnie uzasadnienie [jednolitego] stylu życia, otóż ta epoka nie może dysponować ani stylem ornamentalnym, ani choćby motywami dekoracyjnymi, w których znalazłby odzwierciedlenie powszechnie obowiązujący wyraz czasu, nie może też mieć zrozumienia dla istoty ornamentu w przeszłości ${ }^{18}$.

Zdanie to zachowuje bez wątpienia aktualność i dzisiaj19.

Pod wpływem swych przyjaciół z Berchtesgaden zwrócił Berliner w tym czasie uwagę na znaczący i dobrze już przebadany przez Georga Hagera zbiór szopek bożonarodzeniowych z kolekcji Bayerisches Nationalmuseum. W 1926 r. rozpoczął publikację Dankmäler der Krippenkunst [„Pomniki sztuki szopkarskiej”] w augsburskim wydawnictwie Filsera; w 1930 r. przedsięwzięcie trzeba było jednak ze względów finansowych przerwać. Z delikatną tylko nutką goryczy zanotował potem, że w $1933 \mathrm{r}$. podjęto się wydania zebranego przez niego materiału, „by roztrwonić go z pominięciem mojego imienia" 20 .

W 1931 r. ukazała się nakładem Niemieckiego Stowarzyszenia Historii Sztuki (Deutscher Verein für Kunstgeschichte), opracowana przez niego i dyrektora Beyerisches Nationalmuseum, Philippa Marię Halma, edycja iluminowanego aschaffenburskiego inwentarza Hallesches Heiltum, zestawionego z polecenia magdeburskich arcybiskupów Ernsta Wettyna i Albrechta Brandenburskiego na przełomie XV i XVI wieku²1.

Potem przyszedł rok 1933 i przejęcie władzy przez narodowych socjalistów. Przez wzgląd na służbę frontową [podczas pierwszej wojny świa-

$18 \mathrm{OV}$, s. 113; jako uzupełnienie uwagi do traktatu o ornamencie z roku 1775 (s. 115): „W dydaktycznym zwrocie (...) w dedykacji objawia się już fatalna zmiana zapowiadająca czasy, które nie znają już niepodzielnego świata form artystycznych jako konieczności wyrazu, lecz które charakteryzuje podział na prawdziwe, wybujałe życie artystyczne dnia bieżącego i zasadniczo historyzujące, konserwujące kształcenie artystyczne, czasy, mówiąc krótko, w których pytaniem o kształcenie staje się: czym była niegdyś siła żywotna. Ambicją staje się mieć w niej udział”.

19 Do wyjątków należą studia zmagające się z tym deficytem, jak: W. Wolters, Architektur und Ornament. Venezianischer Bauschmuck der Renaissance, München 2000.

${ }^{20}$ WK, s. 9 (przyp.).

21 J. Rasmussen, Untersuchungen zum Halleschen Heiltum des Kardinals Albrecht von Brandenburg, „Münchener Jahrbuch der bildenden Kunst” 27, 1976, s. 91-132. 
towej] początkowo nie dotknęły Berlinera zapisy „Prawa o przywróceniu niemieckich urzędników" (Gesetz zur Wiederherstellung des deutschen Beamtentums), nakazujące zwolnienie wszystkich Żydów i domniemanych przeciwników reżimu ze służby państwowej. Tym bardziej ostentacyjnie uwidocznił się przestępczy i samowolny charakter rządów narodowych socjalistów, gdy w lipcu 1933 r. Berliner, z pogwałceniem wszelkich norm prawnych, został aresztowany przez policję w swym domu w Berchtesgaden i uprowadzony. Hitler i jego akolici mieli przy tym pewnie na oku dom Schneewindellehen, w którym potem na czas jakiś rozkwaterowali się Martin Bormann i Heinrich Himmler. Miejsce internowania Berlinera - obóz koncentracyjny w Dachau - utajniono. Rodzina poruszyła wszelkie tryby, by go odnaleźć; zwrócono się między innymi do zajmującego w tym czasie katedrę historii sztuki w Monachium Wilhelma Pindera, który pomógł w odszukaniu uprowadzonego ${ }^{22}$. O tym, jak mało znaczyły wówczas prawa i przepisy, niech świadczy fakt, że ostatecznie to handlarz sztuką Eugen Brüschwiler, który jako jeden ze stu pierwszych członków NSDAP posiadał wiążącą się z szeregiem przywilejów złotą odznakę partyjną, ubrany w mundur SS i w towarzystwie dyrektora muzeum Buchheita, pojechał do Dachau i tam zażądał i przeforsował wydanie więźnia.

Ale Berliner został napiętnowany. W dniu 31 grudnia 1935 r. został zwolniony z muzeum. Zdał swoje monachijskie mieszkanie przy Möhlstrasse, jednej z najpiękniejszych ulic dzielnicy Bogenhausen - m.in. dlatego, że położone było zbyt blisko głównej kwatery SA - i wycofał się do swej posiadłości w Berchtesgaden, by tam kontynuować studia nad Arma Christi i szopkami bożonarodzeniowymi. Swych obu synów wysłał przezornie do Stanów Zjednoczonych ${ }^{23}$. Sam także szukał tam zatrudnienia,

22 Wilhelm Pindar napisał w swoim wniosku o denazyfikację, że Berliner został uprowadzony przez SS i że on wraz z Brüschwilerem uratowali go.

23 Starszy syn Michael Wolfgang Berliner (później przyjął nazwisko Bever), 7 VIII 1911 - 14 VII 1992, uzyskał w 1934 r. stopień doktora prawa na uniwersytecie w Heidelbergu. W tym samym roku wyemigrował do USA, w 1937 zdobył stopień Master of Business Administration na Uniwersytecie Harvarda, by następnie zwrócić się ku studiom w zakresie metalurgii w Massechusetts Institute of Technology, w którym w 1944 r. doktoryzował się i zrobił następnie błyskotliwą karierę, uzyskując uznanie jako profesor i badacz jakości materiałowych metali, zwłaszcza pionier recyclingu. Drugi syn Christoph Friedrich Wilhelm Theodor Berliner, ur. 12 III 1919, również przyjął po matce nazwisko Bever, imieniu nadał natomiast angielskie brzmienie Christopher. Po studiach, m.in. w zakresie historii sztuki na Harvardzie, zwrócił się ku medycynie i został ostatecznie psychoanalitykiem. Na temat obu synów zob. różne wydania Who is Who in America i American Men \& Women in Science. Wedle wypowiedzi Christophera Bevera ojciec nienawidził Freuda, Junga i całej psychoanalizy. Podśmiewał się także z filologa klasycznego i autora znanej książki Bogowie Grecji (Die Götter Griechenlands) - a zarazem męża najbliższej 
było to jednak zbyt trudne do przeprowadzenia. Po tzw. nocy kryształowej jego położenie stało się jeszcze bardziej krytyczne. 27 stycznia 1939 r. zmuszono go do przyjęcia dodatkowego imienia Israel. W ostatniej niemal chwili udało mu się wyjechać, mógł nawet zabrać wiele potrzebnych do życia rzeczy ${ }^{24}$. Mógł wziąć $\mathrm{z}$ sobą również liczącą około dwóch tysięcy tomów bibliotekę, po części odziedziczoną jeszcze po ojcu ${ }^{25}$. Służący z Berchtesgaden zaopiekowali się cennym, a niemożliwym do wywiezienia dobytkiem rodziny, by w 1945 roku zwrócić go prawowitym właścicielom w nienaruszonym stanie. Inni członkowie rodziny mieli mniej szczęścia i stracili życie.

Rudolf Berliner służył z oddaniem swym nowym pracodawcom, najpierw Cooper Union Museum w Nowym Jorku, potem muzeum w Providence $\mathrm{w}$ stanie Rhode Island, wreszcie waszyngtońskiemu Textile Museum. A jednak po 1945 r. zdecydował się wrócić do Monachium. Odbudował dawne kontakty i nawiązał nowe, w tym z jezuitą Herbertem Schadem oraz Lenzen Kriss-Rettenbeckiem. Nie znalazł się wszakże nikt, kto umożliwiłby wówczas już sześćdziesięcioletniemu Berlinerowi powrót do pracy muzealnej, czy to $\mathrm{w}$ Beyerisches Nationalmuseum, czy gdziekolwiek indziej w Niemczech. Nic nie świadczy jednak o tym, by ten kiedykolwiek uskarżał się na swój los. Poprawa kondycji finansowej, wskutek m.in. sprzedaży odzyskanego Schneewinckellehen, dała mu możliwość pracy jako prywatny uczony i podejmowania podróży studyjnych - zimy spędzał w Ameryce, lata w Monachium, Rzymie lub innych miastach $^{26}$. Po jego śmierci 6 sierpnia 1967 r. ukazało się kilka nekrolo-

przyjaciółki jego żony - Waltera F. Otto. Berliner nie chodził do kościoła, określał się raczej jako agnostyk, był krytyczny wobec żydostwa, całą sympatię przelewając na Kościół wczesnochrześcijański - stąd niektórzy amerykańscy koledzy drażnili go, nazywając „Early Christian Berliner”. Tolerował poszukiwania żony odpowiadającej jej wiary, jej okresowe zainteresowanie buddyzmem i jej (a także ich syna Michaela) przejście na unitarianizm.

${ }^{24}$ D. Wutke (red.), Erwin Panofsky: Korrespondenz, Bd. 1: 1910-1936, Wiesbaden 2002, opublikował (s. 949-950) list Berlinera z 6 grudnia 1936 r., w którym prosi on Panofsky'ego o pomoc przy przenosinach do Ameryki. Z innego, nie opublikowanego dotąd listu z 24 IV 1937 r. wynika, że Berliner spotkał się w 1937 r. z Panofskym w Princeton celem omówienia dalszych kroków.

${ }_{25} \mathrm{~W}$ cytowanym w przyp. 1 liście Christophera Bevera wymienionych zostało wiele książek, m.in. obszerny zbiór klasyków literatury niemieckiej; zwraca uwagę uprzywilejowanie Goethego i wyraźna obecność Herdera, Nietzschego i Burckhardta. W tym samym liście znajdują się również słowa wskazujące na muzyczne zamiłowania Berlinera i jego działalność jako organisty.

${ }^{26}$ Przyjaciel Martin Weinberger wystarał się o prowadzenie przez niego kursu muzealnictwa w New York Institute of Fine Arts. W dokumentach Bayerisches Nationalmuseum występuje Berliner jako profesor nadzwyczajny Uniwersytetu Monachijskiego; stanowisko to nie znajduje potwierdzenia w dokumentach Archiwum Uniwersyteckiego. 
gów ${ }^{27}$. Ale ranga jego osiągnięć nie znalazła należnego uznania, nie stało się tak w każdym razie w dyscyplinie historii sztuki. Poniższe uwagi są próbą zadośćuczynienia.

\section{SZTUKA SZOPEK BOŻONARODZENIOWYCH (DIE KRIPPENKUNST)}

„Książka, którą czytelnik otrzymuje do ręki, stanowi rezultat trzydziestoletnich wysiłków" - tak rozpoczyna się przedmowa do wydanego w 1955 r. dzieła o bożonarodzeniowych szopkach. Jest to bardzo gęsty, przeładowany danymi faktograficznymi tekst, który nie poddaje się pobieżnej lekturze. Ważne rozważania metodologiczne, dłuższe dygresje odnośnie do kwestii szczegółowych, znaczące odkrycia i poglądy, są w przypisach raczej ukryte ${ }^{28}$. Jednak kto przestudiuje książkę dokładnie, zostanie sowicie wynagrodzony. A przecież Berliner nie traktował jej jako dzieła wyczerpującego temat, lecz jako impuls do pogłębionych badań nad zaniedbanym przedmiotem.

Jego intencje są lepiej czytelne w tytule wydanych w 1926 r. Pomników sztuki szopkarskiej (Denkmäler der Krippenkunst) niż w tytule Szopka bożonarodzeniowa (Die Weihnachtskrippe). Z pewnością był on historykiem sztuki w nadzwyczajnym stopniu zainteresowanym ludową religijnością i ludową sztuką; a przecież chodziło mu przede wszystkim o to, by bożonarodzeniową szopkę traktować jako specyficzny gatunek sztuki, by uwolnić ją od krzywdzącej etykietki „dziecięcej zabawki” i ludowego zwyczaju bożonarodzeniowego, by pojmować ją jako szczególnego rodzaju „rekonstruującą sztukę religijną”29. Niestety - powiedzmy od ra-

27 Th. Müller, „Kunstchronik” 20, 1967, s. 331 i n.; „Das Münster” 20, 1967, s. 501; Stefanucci (jak w przyp. 3); D. Schmidt, Warheit im Anschaulichen, „Süddeutsche Zeitung” Nr 209, 1 IX 1967.

${ }^{28} \mathrm{~W}$ tomie o bożonarodzeniowych szopkach warte podkreślenia są m.in. tematy: (s. 66, przyp. 460 i n.) faworyzowania pochodu trzech króli w zegarach i automatach począwszy od XIV w.; (s. 77 i przyp. 530) o przeznaczonej na eksport wytwórczości snycerzy z Berchtesgaden; (s. 159, przyp. 48) o znaczeniu motywu kąpieli Dzieciątka Jezus wraz $\mathrm{z}$ ważnymi rozważaniami nad charakterem narracyjnych obrazów dewocyjnych; (przyp. 250) o kształtowaniu w wosku; (przyp. 21) o krucyfiksach z prawdziwymi włosami; (przyp. 677) o cartapesta [papier-mâché]; (przyp. 741) o znaczeniu rozsyłania ustrojonych lalek. Analogicznie w artykule XII, s. 102, przyp. 17.

${ }^{29}$ WK, s. 190, przyp. 329: „Spór, czy szopka może w ogóle należeć do obszaru „sztuki”, wydaje mi się jałowy, bo zależy od przyjętych za punkt wyjścia definicji. Najpierw należałoby rozważyć, czy sztuka ludowa oznacza zawsze nie-sztukę, czy też może raczej obowiązuje w niej to samo kryterium odgraniczające, co w przypadku „sztuki kształconej” (gebildete Kunst) (Weimarer Kunstfreunde), tj. jakość. Szopka stanowi artystyczne zadanie, którego cel, mianowicie możliwie dobitne oddanie rzeczywistości, pokrywa się z celem sta- 
zu - celu tego nie udało mu się osiągnąć. Oczekiwanie, że naukowe wywody i argumenty oddziałają oświecająco, nazbyt często okazuje się złudzeniem. Można by wskazać na podobne zjawiska w Starożytnym Egipcie albo Grecji, albo gdziekolwiek bądź, ale w niewielkim stopniu dałoby się za ich sprawą naruszyć dominujący sposób pojmowania sztuki i zwyczajowy podział na gatunki artystyczne; te zaś skutkują raczej nieufnością wobec bożonarodzeniowej szopki - ze względu na jej pokrewieństwo z teatrem i zabawą - i to mimo jej wielkiej, a nawet rosnącej popularności.

Romantyzującemu przemienieniu (Verklärung) „ludu” i ludowości był Berliner bardzo niechętny; spoglądał na wszystko okiem krytycznym i trzeźwym:

Do najbardziej zadziwiających nieporozumień odnośnie do szopki z Neapolu należy to, że nie rozpoznano, o jak wzniosły świat tutaj chodzi. „Ludowe” w niej jest to tylko, że przedstawia ona postaci z ludu i że lud żywo na nią reaguje (...), ale nie mamy tu do czynienia z samoprezentacją ludu, lecz z "folklorem odgórnym" (Folklore von oben). Ubogiemu, cierpiącemu, udręczonemu ludowi odpowiadałoby z pewnością coś innego (...).

Jest to zarazem wspaniały $\mathrm{z}$ metodologicznego punktu widzenia głos w kwestii realizmu ${ }^{30}$.

Dla niego stanowiły te na wpół efemeryczne realizacje, wystawiane, inaczej niż retabula ołtarzowe, tylko okresowo (z reguły od Bożego Narodzenia do święta Matki Bożej Gromnicznej) i stąd każdego roku nieco inaczej wyglądające, szczególny gatunek obrazu chrześcijańskiego, który - ponieważ nie respektował granic pomiędzy gatunkami sztuki, a także pomiędzy sztuką a teatrem - ściągnąć musiał na siebie nieprzychylność estetycznych dogmatyków. Szopka była zarazem trwała i efemeryczna, zabawowa i poważna. Stąd sprzeciwiała się etosowi moderny i obowiązującym w niej normom - dlatego ta wydała na nią wyrok skazujący.

Usiłowania Berlinera zmierzały do tego, by wykazać samodzielność szopki wobec retabulów ołtarzowych, ale także grup Grobu Świętego, przedstawień misteryjnych, żywych obrazów i tym podobnych praktyk

wianym nierzadko w tak zwanej sztuce ludowej. Bez wątpienia nieczęsto w nowszych czasach spotykały się w sposób tak naturalny sztuka dla ludu i sztuka ludu”.

30 WK, s. 104. Zob. także ogólne rozważania o sztuce ludowej, na s. 42; o „ludowości” nowego zwyczaju jako zachęty do jego propagowania przez wczesnych rzeczników kontrreformacji na s. 27; o tym, że od XIX w. pozostawiono sztuce ludowej realizowanie potrzeb, na s. 153. Wśród przedstawicieli ludoznawstwa zdobył Berliner większe uznanie niż wśród historyków sztuki. Został mu poświęcony numer „Beyerisches Jahrbuch für Volskunde” z 1966/67 r., rozpoczynający się artykułem Lenza Kriss-Rettenbecka, Anmerkungen zur neueren Krippenliteratur, s. 7-36; znaleźć tam można jednak również - np. na s. 12 - ideologicznie zaślepioną krytykę Berlinera, płynącą właśnie z kręgów ludoznawczych. 
teatralnych, a także do rozpoznania jej genezy i wczesnych dziejów ${ }^{31}$. Zawdzięczamy ją nie, jak dotąd uważano, franciszkanom, lecz dewocji prywatnej. Punktem wyjścia były wielopostaciowe, rozbudowane przestrzennie retabula XV-wieczne, przede wszystkim pochodzenia północnośrodkowoeuropejskiego. Bożonarodzeniowa szopka „miała wzmóc uczuciowość pobożnych, pomóc im wkroczyć na scenę historii świętej, by w ten sposób tym głębiej pogrążyli się w medytacji nad drogą zbawienia (...). Jest [ona] pomocą w duchowej pielgrzymce (...). [Chodziło o] przeniesienie „transaemus usque Betlehem” pasterzy (Łk, 2, 15) w bezpośrednią współczesność"32. Ludzie zamożni budowali szopki domowe w formie niezmiernie nieraz kosztownych dzieł sztuki złotniczej, niektóre z nich wyobrażać musimy sobie jako bardziej wystawne niż Goldenes Rössl z altöttingskiego skarbca ${ }^{33}$. Z domów i klasztorów trafiła w końcu szopka do kościoła ${ }^{34}$. Jej zwyczaj został spopularyzowany przez jezuitów i inne zakony kontrreformacji.

Szopka jest totalnym dziełem sztuki swoistego rodzaju (Gesamtkunstwerk eigner Art). Początkowo nie było wyspecjalizowanych w niej artystów, stąd nigdy nie była dziełem jednego artysty, lecz zawsze wynikiem pracy zespołowej; bardzo rzadko powstawała od jednego rzutu, lecz stopniowo była uzupełniania i zmieniana. W różnym zakresie zaangażowani przy tworzeniu szopki byli rzeźbiarze, malarze, architekci, odlewnicy w wosku, krawcy i dekoratorzy ${ }^{35}$; nie należy wreszcie lekceważyć roli amatorów-dyletantów ${ }^{36}$. Szopka wymaga inscenizacji, choćby oświetlenia ${ }^{37}$. Jest „zastygłym teatrem”, różni się od niego jednak już choćby tym

${ }^{31}$ Definicja - zob. WK, s. 14 i n.; znaczenie i użycie słów Krippe (szopka), praesepe etc. s. 19 i n.; odróżnienie od retabulów s. 25 i n. Berliner jasno formułuje trudności metodologiczne: „Wszelkiej historii bożonarodzeniowej szopki służyłaby zasadniczo wiara w nieustanie zmieniające się okoliczności” (WK, s. 35); „Również tutaj okazuje się zatem, że problem «możliwości» bożonarodzeniowej szopki nie daje się rozwiązać w wąskich ramach" (s. 28); „Ale rzeczywistość była jak zwykle bogatsza, niż jawi się ona w historycznej abstrakcji” (s. 93). Typowe jest również krytyczne wprowadzenie do stanu badań nad szopką neapolitańską (s. 96), które skutkuje zdaniem: „Pewnym jest, że wcześniej utrzymywano, że wie się mniej, później - że więcej."

32 [„Pójdźmy do Betlejem”; WK, s. 14.

33 WK, s. 13 i n., 28.

${ }^{34}$ WK, s. 24, o fundacji szopki bożonarodzeniowej przez biskupa Dawida Burgundzkiego dla katedry w Utrechcie w 1489 r.; wartość użytego do jej wykonania materiału wyceniono w momencie jej przetopienia w 1578 r. na ponad 150 tys. guldenów.

${ }^{35} \mathrm{Na}$ temat udziału przedstawicieli poszczególnych rzemiosł zob. WK, s. 49, 79, 100 i n.; na temat strojów także s. 47, 85, 170; o figurach woskowych s. 35, 64, 73, 85 i n., 100 i 136.

${ }^{36} \mathrm{O}$ roli dyletantów zob. m.in. WK, s. 81 i 111.

37 WK, s. 10, 13, 34, 38 i n., 40 i n. etc. „Jej (...) teatralność polega także na tym, że figury wymagają ostrego oświetlenia. W matowym świetle dnia tracą wiele”. 
tylko, że nie jest ograniczona fasadowo obramowaną sceną, lecz rozwija się swobodnie w przestrzeni, stąd stosunek odbiorców do niej jest zupełnie odmienny. Oferuje ona ogląd panoramiczny i umożliwia włączenie się $\mathrm{w}$ przedstawione wydarzenie; budzi zaciekawienie, ale utrzymuje wyobraźnię na wodzy; pozwala spojrzeniu błądzić, ale przecież zawsze kieruje je w końcu ku świętemu punktowi centralnemu.

Ponieważ kompozycja taka jest ze swej istoty wielofigurowa i bogata w sztafaż, opracowaniu poszczególnych postaci poświęca się mniej uwagi, niż ma to zwyczajowo miejsce w rzeźbie ołtarzowej. Umieszczana początkowo na ołtarzu właśnie lub w jego bliskości i ograniczona w tym wczesnym okresie przez architektoniczną ramę, wkrótce rozwinęła się przestrzennie: „czarodziejski dom” (Zauberhaus) zmienił się w „czarodziejską górę" (Zauberberg) ${ }^{38}$. W wielu realizacjach przedstawiona była nie tylko jedna scena, lecz na wzór narracji kontynuacyjnej, cała sekwencja wydarzeń bożonarodzeniowych, z uprzywilejowaniem sceny adoracji pasterzy lub królów. Ich wystawienie wymagało niebawem więcej niż jednego pomieszczenia; bożonarodzeniowa szopka zdaje się prefiguracją nowożytnej panoramy ${ }^{39}$. Właściciele największych dzieł nierzadko udostępniali je publiczności; najbardziej spektakularne odnotowywano wręcz w przewodnikach turystycznych. Gdy spodziewano się wizyty osób wysokiego stanu, dbano o oprawę muzyczną. Zbliżała się w ten sposób szopka do ulubionej formy teatralnej epoki - do opery. Nie dziwi zatem wykorzystanie w niej maszynerii i automatów ${ }^{40}$. Nakłady, jakie ponoszono dla wystawienia szopki w okresie jej największego rozkwitu, przewyższać mogły koszt budowy całego kościoła wraz z wyposażeniem ${ }^{41}$.

A jednak

podzieliły los wszystkich obiektów dewocyjnych: szanowane i otoczone opieką, gdy dewocja kwitła, popadły w nieprawdopodobne zaniedbanie, gdy praktyki dewocyjne osłabły, jak gdyby chciano ukarać je za to, że one właśnie, stosiki materii, były przyczyną i celem tak silnych emocji. Ale już to pierwsze jest zagrożeniem dla ich wyglądu, bo miłość chce znaleźć swój wyraz - w ozdobie, uzupełnieniu, jakkolwiek bądź; z drugiej strony należy zachować możliwość od-

38 WK, s. 83.

39 S. Oettermann, Das Panorama. Die Geschichte eines Massenmediums, Frankfurt/M. 1980.

40 WK, s. 64 i n., 80 i przyp. 457 i 460.

${ }^{41}$ Szopka dla klasztoru kanoników regularnych w Diessen nad Ammersee kosztowała 1500 guldenów (WK, s. 135); słynna w mieście, wystawiana corocznie od 1775 r. szopka w kościele przy szpitalu św. Józefa w Monachium - 4000 guldenów (s. 136). Podobną sumę potrzebował Balthasar Neuman dla wystawienia zleconego przez arcybiskupa Friedricha Karla v. Schönborn kościoła Św. Krzyża w Kitzingen-Erwashausen w l. 1740-1745. 
działywania, a dzieje się tak tylko w przypadku, gdy wygląd prac odświeżany jest od czasu do czasu $(. . .)^{42}$.

Berliner z tą samą intensywnością brał pod uwagę różne kraje i centra na przestrzeni dziejów, specyfikę sztuki szopkarskiej w klasztorach żeńskich i innych instytucjach kościelnych, w kościołach parafialnych i w prywatnych domach. Jego książka stawała się w ten sposób historią społeczną i historią religijności. Był otwarty na wszystko, co służyło zrozumieniu dzieł, a zarazem uważny, by nie pogwałcić przedmiotu badań, by własnej osoby nie wysuwać na plan pierwszy - a wszystko to w czasie, który nie potrafił wypracować metodyki całościowej i elastycznej i który nie cenił bynajmniej tego, kto porzucał poglądy większości, by podążać własną ścieżką43.

Berliner natrafił jednak również na inne trudności. Już w 1929 r. skarżył się na marny stan badań nad historią egzegezy:

Ponieważ brakuje historii egzegezy psalmów, przy wyjaśnianiu znaczenia psałterzy dla sztuki chrześcijańskiej otwiera się luka niemożliwa do wypełnienia przez historyka sztuki. Jak się wydaje, znaczenie egzegezy dla wyjaśnienia przedstawień sztuki chrześcijańskiej w ogóle nie zostało dotąd rozpoznane. (...) Że sztuka czerpała swoje wyobrażenia ze wszystkich obszarów teologii oraz kościelnego i religijnego życia, jest przecież oczywiste. Potrzebujemy zatem teologii sztuki chrześcijańskiej, która potrafiłaby wyczytać z dziejów sztuki, jak myśl teologiczna i religijne życie - ale także odstępstwa od nich - odzwierciedlają się w jej dziełach. (...) Historyk sztuki, świadom, że jego dzieło jest zawsze fragmentaryczne i niewystarczające, musi podjąć próbę wyjaśnienia tych zagadnień, choćby po to, by błędy jego stanowiły pobudkę do podjęcia ich przez bardziej rozumnych, którzy w najlepszym razie mogliby wówczas odnaleźć drogowskazy, w którym kierunku muszą wytyczać drogę $e^{44}$.

Dlatego zareagował potem tak entuzjastycznie na książkę Aloysa Grillmeiera z historii dogmatyki pt. Der Logos am Kreuz z 1956 r. (XI) i wykorzystał uzyskaną dzięki niej wiedzę w swym ważnym opracowaniu poświęconym przestawieniom nauki o „dwóch naturach Chrystusa” (XIII) ${ }^{45}$. Zgłoszony postulat, by ściślej powiązać historię sztuki z historią teologii i religijności, musiał Berliner spełnić sam. Ostatecznie we wszystkich jego studiach chodzi o to, by przybliżyć się do wyjaśnienia istoty obrazu chrześcijańskiego poprzez odwołanie do najważniejszych nauk: o Wciele-

42 WK, s. 53 i n.

${ }^{43}$ Por. uwagi odnośnie do Hansa Jantzena w przyp. 4 Przedmowy [nie publikowanej tutaj].

44 III, s. 106.

45 Według informacji Lenza Kriss-Rettembecka pod koniec życia interesowało go niezmiernie pytanie, jak należy wyobrażać sobie przemienione ciało Chrystusa. 
niu, o dwóch naturach Chrystusa, o mariologii etc., a także o to, by wykazać, że obrazy stanowić mogą samodzielne, niezależne od słowa wypowiedzi na ten temat.

Głównym celem bożonarodzeniowej szopki jest aktualizacja świętego wydarzenia i umożliwienie identyfikacji widza $\mathrm{z}$ jego bohaterami ${ }^{46}$. Prace Berlinera poświęcone rozumieniu rzeczywistości i oddziaływania obrazu chrześcijańskiego są zatem zarazem głosem w dyskusji na temat „realizmu" w sztuce zachodniej, głosem o podobnym znaczeniu, co wypowiedzi Ericha Auerbacha. Także dla Berlinera rozstrzygająca dla genezy realistycznego, mimetycznego, w coraz większym stopniu emocjonalnego sposobu przedstawiania, rozwijającego się od późnego średniowiecza, jest specyfika religii chrześcijańskiej; tyle że on wywodzi ten proces z zyskującej na znaczeniu nauki o człowieczeństwie, względnie o dwóch naturach Chrystusa ${ }^{47}$. Miał na względzie nie tylko zerwanie $\mathrm{z}$ antyczną nauką o stylach retorycznych, w wyniku którego niski styl sermo humilis podniesiony został do stosownej „mowy chrześcijańskiej”. W jego przekonaniu nauka o człowieczeństwie Jezusa z Nazaretu prowadziła w długiej perspektywie do innego postrzegania wszystkiego: warunkowała pozytywne wartościowanie lekceważonej dotąd rzeczywistości, nie odczytując tej zmiany fałszywie jako sekularyzacji. Przy czym to spojrzenie ku rzeczywistości nie jest równoznaczne $\mathrm{z}$ wiernym przedstawianiem natury, historycznego miejsca i historycznego czasu:

Roszczenia poszczególnych czasów i reprezentantów poszczególnych poziomów wykształcenia wobec tego, co odczuwają oni jako realistyczne, są różne. Jednak

${ }^{46}$ WK, s. 9. 13. Bardzo piękne są pasaże poświęcone motywowi kąpieli nowonarodzonego Chrystusa, który uzasadnia szeroko rozpowszechnionym w konwentach żeńskich późnego średniowiecza wyobrażeniem o naśladowaniu Marii jako pielęgnującej Dzieciątko Jezus.

47 E. Auerbach, Mimesis. Dargestellte Wirklichkeit in der abendländischen Literatur, Bern 1946 i wiele późniejszych wydań. Na temat „dyskusji o realizmie” u Berlinera zob. WK, s. 28 i n., 78 i n., 103, 159, przyp. 48, s. 175, przyp. 173 etc. Na s. 51 i n. o znaczeniu integracji postaci proroków i innych figur typologicznych w szopce dla rozumienia „czasu” w kontekście historii świętej. Zob. także: F.P. Pickering, Literatur und darstellende Kunst im Mittelalter, Berlin 1966 (= Grundlagen der Germanistik 4); J. Marrow, Passion Iconography in Northern European Art of the Late Middle Ages and Early Renaissance. A Study of the Transformation of Sacred Metaphor into Descriptive Narrative, Kortrijk 1979 (=Ars Neerladica 1); Gerhard Schmidt, „Pre-Eyckian Realism”. Versuch einer Abgrenzung, (w:) M. Smeyers / B. Cardon (red.), Flanders in a European Perspective. Manuscript Illumination around 1400 in Flanders and Abroad. Proceedings of the International Colloquium Löwen, 7.-10. IX. 1993, Löwen 1995, s. 747-769; R. Suckale, Zum Körper- und Wirklichkeitsverständnis der frühen niederländischen Maler, (w:) K. Schreiner i in. (red.), Frömmigkeit im Mittelalter. Politisch-soziale Kontexte, visuelle Praxis, körperliche Ausdrucksformen, München 2002, s. 271-296. 
co do jednego wymagania zgadzają się chyba wszyscy: życie oznacza wypełniającą przestrzeń cielesność, oznacza ruch w przestrzeni. Dwuwymiarowość może stworzyć (...) „obraz”, ale będzie brakować mu doświadczenia głębi, rozstrzygającego dla pomyślnej rekonstrukcji rzeczywistości ${ }^{48}$.

Aktualizacja (Vergegenwärtigung) w sztuce chrześcijańskiej przezwyciężyła nie tylko przestrzenny, ale także historyczny dystans; przeniosła wydarzenie we własną przestrzeń życiową, ale zarazem przemieszała ją ze światem innym, obcym, tajemniczym i wspaniałym ${ }^{49}$.

A jednak ogląd obrazów (i bożonarodzeniowych szopek) był zawsze rozumiany wyłącznie jako etap przejściowy do wyższego oglądu duchowego, jak to ujmuje w Mszale Rzymskim Prefacja o Narodzeniu Pańskim: „ut dum visibiliter Deum cognoscimus, per hunc in invisibilium amorem rapiamut"50. Przypomina to rozpowszechnioną od XII wieku teorię, wedle której przy wznoszeniu się duszy ku Bogu obrazom przyznana zostaje jedynie rola stopnia wstępnego. W tym podobna była szopka do teatru i musiała często służyć jego usprawiedliwieniu ${ }^{51}$.

\section{STUDIA NAD OBRAZAMI PASYJNYMI I WOLNOŚĆ SZTUKI ŚREDNIOWIECZNEJ}

Bożonarodzeniowa szopka odsłania przed nami jaśniejszą, radośniejszą stronę historii świętej, która człowiekowi wczesnej nowożytności bliższa była niż mroczna, jakkolwiek wspaniała, gloryfikacja cierpienia i śmierci Jezusa Chrystusa. A jednak to męka i osoba Zbawcy stanowi centralny punkt chrześcijaństwa i stosownie do tego także główny temat studiów Berlinera, w których pisał:

pragnąłem, wykraczając poza utarte ogólniki, przedstawić ścisły związek między rozwojem przedstawienia w sztuce danego tematu a jego miejscem w życiu religijnym i jego opisem słownym. O ile trzy pierwsze (Strqcenie do Cedronu, Madonna w sukni w kłosy (Ährenmadonna), Są Piłata [tj. I, II, III]) doprowadziły do zrozumienia przedstawień rzadkich, o tyle byłem (...) zaskoczony [podczas stu-

48 WK, s. 13, tamże również kolejne zdania.

49 WK, np. s. 53 i n.

50 [,abyśmy poznając Boga w widzialnej postaci, zostali przezeń porwani do umiłowania rzeczy niewidzialnych”] (WK, s. 31). Jezuici wykorzystywali szopki jako narzędzie „misji wewnętrznej” (Innere Mission): „Bo nic nie odciska się w duchu w ten sposób i nie utrwala się w nim tak mocno, nic nie porusza wiernego bardziej, niż doświadczone zmysłowo (WK, s. 32, za czeskim źródłem). Stosownie do tego odnowili dawny zwyczaj wystawiania Grobu Świętego.

51 WK, s. 40 i n. 
diów przygotowawczych na temat Arma Christi, IX], że nie tylko zachowane w niezliczonych przykładach przedstawienie Zbawcy jako martwego stojącego Chrystusa pozostało niezrozumiane i zakłada zupełnie inny stosunek wobec sztuk przedstawiających niż to powszechnie chrześcijańskiemu średniowieczu przypisywano, ale że wielka liczba innych związanych ze Zbawcą przedstawień notorycznie określana jest błędnie lub niedokładnie ${ }^{52}$.

Prace nad głównym zagadnieniem, tj. Arma Christi, zostały wcześnie daleko posunięte i udostępnione zaprzyjaźnionym kolegom - Campbell Dodgson cytował je już w 1935 r. - ale w druku, w skróconej formie, ukazały się dopiero w roku 1955:

Apel o refleksję uważam za wciąż aktualny, w ciągu ostatnich dwóch dekad rozumienie sztuki chrześcijańskiej nie stało się bowiem bynajmniej dojrzalsze, za to bardziej uzależniło się od teorii nie opierających się na wnikliwej analizie dzieł sztuki ${ }^{53}$.

Przy całym dążeniu Berlinera do formułowania wniosków ogólnych, jego postępowanie było zawsze empiryczne. Nigdy nie dedukował z przyjętych uprzednio pojęć. Stąd na starsze badania spoglądał krytycznym okiem: „Niemiecka historia sztuki potrzebuje pilnie prawdziwie srogiego krytyka (...) [i] duchowej dyscypliny”, pisał w liście do Herberta Schade.

Nie istniało rzekomo zasadnicze przeciwieństwo między obrazami dewocyjnymi a przedstawieniami narracyjnymi, które, ustanowione pod jaką bądź nazwą przez niemieckich historyków sztuki zainteresowanych plastyką późnego średniowiecza, stało się teraz nieomal dogmatem ${ }^{54}$. Jest po prostu nieprawdą, że zasadniczą cechą każdego obrazu dewocyjnego jest wyizolowanie tematu albo jego wizualna interpretacja podporządkowana „absolutnej opowieści” [schlechthinnige Erzählung], albo jego „kontemplatywna” spełnialność (nawet jeśli Panofsky chciał przy pomocy tej mętnej frazy dać do zrozumienia, że treść obrazu leży poza obszarem racjonalności). Każde przedstawienie z historii świętej może być tylko i wyłącznie przedstawieniem świętego faktu. Formalna, tj. obiektywna różnica pomiędzy obrazem dewocyjnym a obrazem stricte narracyjnym czy stricte przedstawiajacym jest bardzo płynna. Przedstawienie nabiera charakteru obrazu dewocyjnego za sprawą związku z dewocją (...). Stąd obrazem dewocyjnym może stać się zarówno przedstawienie wielopostaciowe, jak i stanowiąca jego element

52 IX, s. 116.

53 Ibidem. Na temat Ährenkleidmadonna zob. L. Kriss-Rettenbeck, Lebensbaum und Ährenkleid. Probleme der volkskundlichen Ikonologie. Rudolf Berliner zum 70. Geburtstag, „Bayerisches Jahrbuch für Volkskunde” 1956, s. 42-56. Na temat Arma Christi tenże (jak w przyp. 12).

${ }^{54}$ X, s. 116, przyp. 13. Ogólne uwagi odnośnie do obrazu dewocyjnego m.in. w IX, np. s. 55 i 70. Obszerna, ale niekompletna i w części błędna historia pojęcia obrazu kultowego (w:) K. Schade, Andachtsbild. Geschichte eines kunsthistorischen Begriffs, Weimar 1996. 
pojedyncza figura; szczególnie częstym tego przykładem zdają się postaci Madonn ze scen Bożego Narodzenia, szczególnie bliskie kobietom w epoce bez rozwiniętej opieki ginekologicznej. Nasza wiedza o historii średniowiecznego obrazu dewocyjnego jest jeszcze bardzo ograniczona. Pewne jest tymczasem tyle jedynie, że sięga ona co najmniej drugiej połowy pierwszego tysiąclecia, że bardzo prominentną rolę odgrywały w niej dzieła sztuki wschodniej i że rozsądnym badaniom nad nią musi zawsze towarzyszyć świadomość, że ze względu na szczególne przeznaczenie obrazów dewocyjnych, mianowicie na ich udział w praktykach odbywanych poza budynkiem kościoła, musimy liczyć się z utratą wielu - w tym najważniejszych - dzieł, co dowiedzione dla czasów nowożytnych, choć podawane liczby są fantastycznie zawyżone ${ }^{55}$.

Trafnie krytykuje Panofsky’ego wyobrażenie o prymacie słowa nad obrazem i tegoż neokantowski sposób myślenia:

Czego nie sposób dowieść, zakłada się jako oczywistość: że można wypracować typologię na podobieństwo obowiązującej w archeologii klasycznej (...). Ponieważ chrześcijańska wyobraźnia religijna znalazła znacznie bogatszy wyraz w postrzeżeniu wewnętrznym i w słowach niż w dziełach sztuki i ponieważ religia chrześcijańska pozwala rozwinąć bogactwo sensów i rozmaitość motywów przekraczające po wielokroć możliwości w tym względzie religii starożytnych, wyjaśnienie dzieł sztuki powstałych z inspiracji religii chrześcijańskiej jest o wiele trudniejsze niż powstałych z inspiracji religii antycznych, w których sens każdego motywu uznawany jest za pewny. Jako oczywistą zakłada Panofsky przede wszystkim racjonalną przekładalność każdego przedstawienia na słowa... ${ }^{56}$.

Berliner zwalczał zawzięcie niektóre spośród obiegowych pojęć, w tym pojęcie symbolu, które uważał za nietrafne i nieuzasadnione historycznie:

Należy zdecydowanie podkreślić, że symbolika średniowieczna nie przedstawia konstrukcji [Lehrgebäude] złożonej z matematycznych formuł, nie istnieje bowiem żaden wypracowany system symboli; jest ona natomiast wyrazem sztuki egzegezy, odnajdującej wciąż bogatsze odniesienia dla ustanawianego w mgnieniu oka motywu centralnego ${ }^{57}$.

Sceptycznie wypowiadał się także wobec wywodzenia artystycznych innowacji z wizji mistyczek, choćby Brygidy Szwedzkiej, wizje te bowiem same były często refleksem obrazów. Zadziwiająco wcześnie pojawiają się

55 Por. artykuł z 1927, s. 264, cytowany w przyp. 5 [nie publikowanej tu; M.M.] Przedmowy [E. Panofsky, „Imago pietatis”. Ein Beitrag zur Typengeschichte des „Schmerzensmannes” und der „Maria Madiatrix”, (w:) Festschrift für Max J. Friedländer zum 60. Geburtstage, Leipzig 1927, s. 261-308; M.M.]

56 X, s. 100; zob. także: s. 112 oraz XIII, s. 103.

${ }^{57}$ III, s. 108; zob. także: III, s. 111; V, s. 263; XI, s. 178; XIV, s. 232. 
u niego również ostrzeżenia przeciwko nazbyt naiwnemu wykorzystaniu gregoriańskiej teologii obrazu 58 .

$\mathrm{Z}$ naciskiem wskazywał na znaczenie egzegezy dla niemal wszystkich badanych przez siebie motywów: „Trzeba nieustannie przypominać, że wszystkie «prawdziwe» przedstawienia motywów mają za podstawę pismo. Dowiedzenie tego byłoby jednym $\mathrm{z}$ najbardziej fascynujących osiągnięć historii egzegezy". Ponieważ jednak historii takiej nie było, z podziwu godną pilnością oddał się lekturze niezliczonych tekstów - ze zdumiewająco bogatym, a długo nie docenionym rezultatem ${ }^{59}$. Jego zasługą było rozpoznanie, że genezy wielu idei obrazowych poszukiwać trzeba nie w naukowej teologii, lecz raczej w religijności potocznej. Myśl tę sformułował już w pierwszym z artykułów poświęconych tematom obrazowym, mianowicie traktującym o Straceniu do Cedronu:

Nie wolno zapominać, że mamy do czynienia z symbolicznymi przedstawieniami [Versinnbildlichungen] wyobrażeń pochodzących nie z naukowej teologii, lecz z mediatywnych ćwiczeń pobożnościowych - ze wszystkimi jednostkowymi odstępstwami, jakie na tym obszarze mogą wystąpić. Nie idzie o kwestię wiary, lecz o utrzymanie wyobraźni w ramach wyznaczonych przez biblijną opowieść. Być może brak owego teologicznego osadzenia tłumaczy również, dlaczego sztuka ta nie obroniła się 6 .

W tym samym tekście podejmuje także po raz pierwszy tak go później zajmujący problem relacji między postrzeganiem rzeczywistości a myślą religijną: „Wielce pouczające są rozważania [zawarte w relacji z pielgrzymki z 1508 r. minoryty] Anzelma, który wyjaśnia, że strumień [Cedron] toczy wodę tylko wówczas, gdy zimą pada, i że latem nie pada nigdy, po czym kontynuuje: wierzy się, że wówczas [podczas Męki Chry-

58 I, s. 57; X, s. 104; IX, zwł. s. 54, 80 i 111. Wedle mojej wiedzy, w obronie owego sceptycznego stanowiska stanął w nowszych czasach dopiero zbyt wcześnie zmarły M. Camille, Seeing and Reading. Some Implications of Medieval Literacy and Illiteracy, „Art History” 8, 1985, s. 26-49; L. Duggan, Was Art really the „Book of the Illiterate?”, "Word and Image" 5, 1989, s. 227-251.

59 IX, s. 148, przyp. 781. Zob. także jego wskazówki biblijne w IX, s. 34, 46 i passim; X, s. 101. Należałby go postawić obok Jamesa Marrowa (jak w przyp. 45). Niektóre spośród wykorzystywanych przez niego książek zasługują na szerszą znajomość w kręgach historyków sztuki, choćby: P. de Barry und M. Sibenius, Polyanthea dei erga matrem suam, Köln 1659 czy I. Marracci, Polyanthea mariana, Köln 1683, Rzym 1694.

${ }^{60}$ I, s. 81. Berndt Hamm ukuł na określenie owej tendencji teologicznej, zorientowanej głównie na wspieranie religijności, pojęcie „teologii religijności” (Frömmigkeitstheologie): Frömmigkeit als Gegenstand theologiegeschichtlicher Forschung. Methodisch-kritische Überlegungen am Beispiel von Spätmittelalter und Reformation, „Zeitschrift für Theologie und Kirche" 74, 1977, s. 464-497, oraz Frömmigkeitstheologie am Anfang des 16. Jahrhunderts. Studien zu Johannes v. Paltz und seinem Umkreis, Tübingen 1982 (=Beträge zur historischen Theologie 65). 
stusa] strumień toczył wodę, iuxta prophetiam David (...). Cóż znaczy rzeczywistość wobec możliwości nadania jej zbawczego sensu za sprawą Słowa Bożego?"61.

Bardziej zasadniczo wypowiada się w artykule o sądzie Piłata:

Przyjęcie jej [sentencji wyroku przez neapolitańskiego prawnika Borello, który wbrew osobistemu przekonaniu uznał odnaleziony w Akwilei w 1580 r. dokument za fałszerstwo] zasługuje na szczególne podkreślenie, bo, wykraczając dalece poza jednostkowy przypadek, natychmiast odsłania najgłębsze podstawy dominującej metody naukowej. Gdy dochodzi do starcia pewnej, opartej na doświadczeniu wiedzy $\mathrm{z}$ uświęconym autorytetem, podąża się za tym drugim, nawet jeśli jest się w pełni przekonanym o słuszności swojej wiedzy (...). Konsekwencją postawy naukowej - a można by też rzecz: wiedzy jako konsekwentnej postawy - jest żądanie, którego się nie zna (...). Wielki przełom, który oddzielił nasze myślenie naukowe od średniowiecznego, dokonał się nie w renesansie, lecz w oświeceniu ${ }^{62}$.

Koniecznym jest, aby szerszym kręgom narzuciło się pytanie, czy konwencjonalne metody ustalania zawartości treściowej dzieł dawnej sztuki chrześcijańskoreligijnej wystarczają wciąż dla jej zrozumienia. Zbyt wielu interpretatorów zdaje się zapominać, że religijna sztuka przedstawiająca jest zarówno bezpośrednim wyrazem, jak i samodzielną formą życia religijnego, które może wymknąć się teologicznej kontroli, bo jest pozarozumowym przejawem religijnego ducha. Godne swojej nazwy dzieło sztuki nie może niczym znak pisma obiektywnie utrwalać jakiejś treści myślowej, zdolne jest bowiem do inicjowania myśli innych. Dzieło sztuki zwraca się wprost nie do intelektu, lecz do emocjonalnego życia odbiorcy. Oczywiście, wiele dzieł sztuki dąży jako „ilustracja” do możliwie wiernego przełożenia tego, co sformułowane lub możliwe do sformułowania w słowach, na doświadczenie wizualne. Ale nawet wówczas należy do istoty przekazu wizualnego, że z jednej strony, nie posiada on tej precyzji, do której zdolna jest treść ujęta w słowa, oraz z drugiej strony, może zawierać konkretność, która wyrażona w słowach niesie sens osobliwy, nieprawdziwy albo niewłaściwy z punktu widzenia nauki Kościoła (...) najtrudniejszym problemem, z jakim musi mierzyć się ikonografia, jest stosunek dzieł sztuki, zwłaszcza tych, które stworzone zostały jako swobodne unaocznienie jakiegoś tematu, do rozumowo sformułowanych wyobrażeń religijnych ${ }^{63}$.

Pozycja przyznana dziełom sztuki w życiu duchowym i emocjonalnym uległa zmianie. Możliwa w późnym antyku (...) wiara w zdolność dokonującego się

61 I, s. 74 , przyp. 6.

62 IV, s. 140, przyp. 1 i IV, s. 142.

${ }^{63} \mathrm{X}$, s. 97. To zdanie-motto powtarzał Berliner wielokrotnie w zmienionym nieco brzmieniu, np. w X, s. 99: „Najwyższy już czas, by uznać fakt, że wiele dzieł sztuki w taki sposób obrazuje temat, że racjonalny, zgodny z nauką Kościoła przekład na słowa jest niemożliwy”. Zob. także: XI, s. 178; XIII, s. 89; XIV, s. 227 i inne. 
w akcie czystego oglądu przeniesienia cech tego, co przedstawione, wprost na widza, w większej części wygasła na Zachodzie od późnego średniowiecza ${ }^{64}$. (...) Ale należy do istoty przedstawienia odczuwanego przez wiernych (...) jako realistyczne, że z łatwością pobudza ono doświadczenie obecności, to jest wywołuje poczucie bezpośredniej współczesności tego, co przedstawione, umożliwiając tym samym nawiązanie $\mathrm{z}$ nim bezpośredniego kontaktu. (...) $\mathrm{W}$ zajmującej nas tu epoce, tj. między wiekiem XII a XVIII, przykładami prawdziwej sztuki religijnej były te dzieła, które, sytuując się pomiędzy biegunami wyznaczanymi przez dzieła służące głównie intelektualnemu pouczeniu i dzieła służące głównie estetyce, pozostawiały artyście swobodę w zakresie nadawania tematowi takiej formy, która jako podporządkowana celowi wywołania wrażenia odnajdywała równowagę pomiędzy wymogami prawdziwości i poprawności oraz względami czysto artystycznymi. Oczywistym założeniem była gotowość odbiorcy do religijnego zachwytu wywołanego tym, co widzi. Nie tworzono wówczas dla odbiorców sceptycznych wobec treści dzieła sztuki lub oczekujących od niego jedynie efektu estetycznego ${ }^{65}$. Przedstawiano rzeczywistość będącą przedmiotem wiary.

Należy do istoty człowieka, że jego spontaniczne życie emocjonalne, także w zakresie religijnym, nie całkiem i nie we wszystkich aspektach podlega kontroli wiedzy (...) [Dlatego] chrześcijańskie przedstawienia religijne odznaczać się mogły zadziwiającą wolnością; (...) o ich religijnej wartości rozstrzyga (...) zdolność wzbogacania życia duchowego (...). Jako kryterium dla uznania danego przedstawienia przyjmowano nie zawsze to, czy, przełożone na słowa, odpowiada nauce Kościoła, lecz czy jest ono zdolne do budzenia uczuć uznawanych za pożądane, to jest, czy sprzyjało ono pogłębianiu religijności. Nauka Kościoła, dogmaty pozostawały niewzruszone (...) Od najdawniejszych czasów istniały np. przedstawienia Pokłonu Magów, które nie były i nie mogły być zgodne z jakąkolwiek słowną narracją na ten temat, bo niemożliwe było, by Maria przyjmowała magów, zasiadając na tronie. Celem takich przedstawień nie była prezentacja wydarzeń tak, jak się one dokonały „naprawdę”. Artystyczne ich unaocznienie było autonomiczne, gdyż historyczna wierność musiała ustąpić uczuciu: tak powinno się było wydarzyć, gdyby wydarzyło się właściwie (...). Artyści szli jeszcze dalej, gdy np. wbrew jednoznacznej relacji w Biblii, za to zgodnie ze społecznymi normami, nie przedstawiali ukrzyżowanego Chrystusa nagiego ${ }^{66}$.

Tylko w ten sposób mogło dojść do tego, że Chrystus przedstawiany był wręcz jako kobieta: „Za zupełnie antropomorficzne można uznać wyobrażenie Boga [jako postaci kobiecej dla wyrażenia Jego istoty jako Miłości]”67. Berliner nie mógł ukryć zdziwienia, ale - dodawał: „(...) jest to

${ }^{64} \mathrm{Na}$ temat procesu racjonalizacji zob. także: IX, s. 60 i n., 78, 136, 139 oraz X, s. 114. 65 Zob. również: V, s. 264, 269 i 279.

$66 \mathrm{~V}, \mathrm{~s} .279 \mathrm{i} \mathrm{n}$.

67 VII, s. 159; wcześniej już w III, s. 105. C.W. Bynum, Jesus as Mother. Studies in the Spirituality of the High Middle Ages, Berkeley i in. 1982 (=Publications of the Center for Medieval and Renaissance Studies University of California in Los Angeles 16). 
tak cudownie ludzkie”68. „Oto (...) otwiera się przeciwieństwo pomiędzy «nieprawdziwym» przedstawieniem wizualnym a historią przekazaną w słowach i nauką"69.

Emocjonalność miała wzmagać uznawaną za życiowy ideał gotowość do naśladowania Chrystusa i Marii. Ale miała ona i głębsze uzasadnienie:

Jest podstawową religijną zasadą, że chrześcijaństwo nie polega na teoretycznej akceptacji dogmatów i faktów („nasza wiedza nie jest niczym innym niż patchwork") , ale na posiadaniu wiary, nadziei i miłości - z nich zaś największa jest miłość (I Kor 13,8,13). „Chrześcijanin to nie ten, kto zna nauki Chrystusa, lecz raczej ten, kto nimi żyje. Postępowanie zatem musi być zdeterminowane przez pragnienie naśladowania (...)”. Dla artysty oznaczało to: „Im skuteczniejsza emocjonalnie jest sztuka (...), w tym większym stopniu może artysta narzucić swój punkt widzenia"70.

Bóg stworzył Adama na swoje podobieństwo, a w Jezusie z Nazaretu przyjął ludzką postać, stąd wszystkie obrazy człowieka wskazują na Boga, a „ludzka natura”, pomimo grzechu pierworodnego, wartościowana jest ostatecznie pozytywnie:

Metafizyczna relacja pomiędzy „przedmiotem” a „obrazem” należy do najbardziej zasadniczych kwestii chrześcijańskiej koncepcji wszechświata. Jeśli przyjąć, że $\mathrm{w}$ zgodzie z naturą ludzkiego umysłu zjawiska nadprzyrodzone mogą być wyobrażone tylko poprzez zmysłowe obrazy, to obraz artystyczny można uznać za siłę fundamentalną ${ }^{71}$.

Sztuka zyskała na ważności także wskutek przekonania, że oko ludzkie jest bardziej wrażliwe niż ucho ${ }^{72}$ :

Duchowy wstrząs, który kazanie albo medytacja mogły wywołać poprzez stopniowe pogrążanie się w następujących po sobie wydarzeniach, dla odbiorcy sztuki możliwy był jedynie poprzez prezentację jednoczesną (...). Stąd przedstawienia synchronizujące, zupełnie „nieprawdziwe”73.

Nie stanowiło przeszkody, że za sprawą egzegezy pojawiały się działania i zdarzenia, o których nie było mowy w ewangeliach; nauka Kościo-

68 VII, s. 159.

69 IX, s. 66.

70 V, s. 273; V, s. 270 i 275. F.O. Büttner, Imitatio Pietatis. Motive der christichen Ikonographie als Modelle der Verähnlichung, Berlin 1983.

$71 \mathrm{~V}$, s. 271.

72 Zob. na ten temat: V, s. 270, 276 i 280 oraz IX, s. 36 i 91. D. de Chapeaurouge, „Das Auge ist ein Herr, das Ohr ein Knecht”. Der Weg von der mittelalterlichen zur abstrakten Malerei, Wiesbaden 1983.

73 IX, s. 48. 
ła głosiła wszak, „że ewangeliści «scripserunt non ad excitandum compassionis affectum principaliter, sed ad faciendum de historia certam fidem»"74. Szczególnie psalmy i profetyczne księgi Starego Testamentu przynosiły egzegetom bogaty plon: „Medytować znaczy w naszym kontekście rozwijać"75.

Dlatego w obrazach dewocyjnych pojęcie czasu, a w konsekwencji także sposób opowiadania, musimy rozumieć inaczej niż byśmy chcieli:

$\mathrm{Tu}$ [w drzeworycie Dürera] nie chodzi o rozwinięcie ludzkiego dramatu, lecz o to, by widz tak przeżył pojedynczą stację, by na skutek wstrząsu straciło dla niego znaczenie wszelkie przed i po, by duszę jego wypełnił bezczas bożego cierpienia i walka o człowieka (...) Dürer nie zawahał się usytuować scenę z Piłatem w niewłaściwym miejscu. Nie ma znaczenia dla oglądu, którego zasadniczym celem jest współuczestnictwo w wydarzeniach, czy ich historyczna kolejność została ściśle zachowana - tak jak nie miało znaczenia dla pielgrzyma w Jerozolimie, czy podążał dokładnie tą samą drogą krzyżową, którą szedł pochód z Chrystusem, o ile w ogóle mógł modlić się w miejscach, które uznawano za „stacje” (...) Jak mało uwagi przywiązywano do biegu wydarzeń, pokazuje przesunięcie karty z Weronika pomiędzy Piotrem i Pawtem, to jest czystego obrazu dewocyjnego, między Upadek pod Krzyżem a Przybicie do Krzyża ${ }^{76}$.

Tym samym pojęcie „synchroniczności”, wprowadzone przez wiedeńską szkołę historii sztuki na potrzeby badań nad narracją, okazało się jedynie pozornie adekwatnym określeniem dla charakterystycznego dla perspektywy chrześcijańskiej wyobrażenia „czasu” w sztukach przedstawiających - niosło jednak niewłaściwą treść. To zaś implikuje odrzucenie formalistycznego, jałowego postulatu autonomii ówczesnego pisarstwa historyczno-artystycznego.

${ }^{74}$ Ewangeliści „pisali nie po to, by przede wszystkim budzić współczucie, lecz po to, by obudzić wiarę w opowiedziane przez nich historie!”, IX, s. 92.

75 IX, s. 124, przyp. 200.

76 II, s. 316 i 317 . Badacze twórczości Dürera nie podążyli za wyjaśnieniem Berlinera, w moim przekonaniu - niesłusznie. O specyficznym rozumieniu czasu w obrazie religijnym zob. III, s. 102; IV, s. 144; IX, s. 39; o początkach „synchronizującego nagromadzenia motywów”, m.in. w odniesieniu do kodeksu Rabbuli z 586 r. pisał on w IX, s. 56: „Także tutaj zniesione zostały wszelkie pojęcia czasu (...)”. Wskazuje poza tym na fakt, że w typie Matki Boskiej Bolesnej, przeżywającej w duchu wciąż na nowo stacje życia własnego i jej Syna, kolejne stacje, w postaci skróconej niczym w Arma Christi, przedstawione są we właściwym porządku: IX, s. 61 i n. i s. 76 i n.; ten typ wywodzi się ze Zwierciadta ludzkiego zbawienia [Heilsspiegel, Speculum humanae salvationis]. Ciekawa jest uwaga Berlinera na temat czasowego przemieszania w obrazach z Arma Christi, IX, s. 82 i 91: „Oko powinno poszukiwać. To właściwe rozpoznanie psychologiczne obecne było bodaj od początku, każąc zrezygnować w obrazach narzędzi Męki Pańskiej z przedstawiania ich w zgodzie z następstwem wydarzeń". 
Oczywiście rozwijało się i zmieniało także myślenie Berlinera ${ }^{77}$ : przywołane przed chwilą pojęcie bezczasu u Dürera poddał potem po części krytyce i zniuansował.

[Nazywa] błędem, który wkradł się do książki p. Reiners-Ernst, że i ona (pod urokiem teorii obrazu dewocyjnego!) obstaje przy tym, jakoby obraz wielkanocny nie nawiązywał ani do Betlejem, ani do Golgoty, jakoby był bezczasowy. Jest to niewłaściwe zarówno z ontologicznego, jak i historycznego punktu widzenia ${ }^{78}$.

Jak jednak trudne także dla niego samego było ujęcie rozumienia czasu w obrazach chrześcijańskich, świadczy sformułowanie zawarte w równocześnie niemal napisanym artykule o Madonnie Sykstyńskiej Rafaela:

(...) owo stopienie historycznego „pewnego razu w przeszłości” z transcendentnym „teraz i zawsze” należało podówczas do prawd wiary, albo może lepiej: do życiowych prawd wiary (...) gdy każdy wiedział przecież, że Maria Dzieciątka nigdy w niebie nie nosiła i nie nosi w ziemskim sensie ${ }^{79}$.

Dopiero chrześcijańskie rozumienie czasu objaśnia tematy „Męża Boleści” i „Arma Christi”. Obraz z narzędziami męki w pasjonale przeoryszy Kunegundy od św. Jerzego w Pradze opisuje Berliner następująco: „Jednocześnie martwa i żywa, historyczna i współczesna, wyprostowana i upadająca, przybita do Krzyża i od niego uwolniona, stojąca, złożona i niesiona postać ta jednoczy sprzeczności niemożliwe do uzgodnienia w porządku naturalnym" 80 . Studia Berlinera nad Arma Christi, jednym z najtrudniejszych tematów pasyjnych, były wezwaniem do zmiany paradygmatu w wyjaśnianiu obrazu chrześcijańskiego. Obrazy o tej tematyce rugowano dotąd jako mniej lub bardziej nieodpowiadające modernie. Przegląd literatury mógłby doprowadzić do wniosku, że ten typ obrazowy stanowił jedynie marginalne zjawisko w sztuce średniowiecznej. Nieproporcjonalnie wiele dzieł o tej tematyce uległo zniszczeniu, bo nie chciał

77 Rzetelność Berlinera objawiała się w tym, że natychmiast komunikował błędy dostrzeżone w swych wcześniejszych pismach i rewidował błędne sądy. Zob. np.: III, s 106, gdzie korekta opinii z I; III, s. 105, gdzie zarzuca sobie dyletanctwo; podobnie IV, s. 134, przyp. 7; IX, s. 120, przyp. 89, z odwołaniem do IV; OV, s. 144, przyp. 1. Z satysfakcją donosił nieraz i o tym, że jego prace znalazły potwierdzenie, choćby w IX, s. 135, przyp. 424 odnośnie do III.

${ }^{78}$ X, s. 113. E. Reiners-Ernst, Das freudvolle Vesperbild und die Anfänge der Pietà-Vorstellung, München 1939 (= Abhandlungen der Bayerischen Benediktiner-Akademie 2); M. Schawe, Fasciculus myrrhae. Pietà und Hoheslied, „Jahrbuch des Zentralinstitugs für Kunstgeschichte” 5-6, 1989-1990, München 1992, s. 161-212.

79 XII, s. 96 i n.

${ }^{80} \mathrm{X}$, s. 106. 
ich mieć żaden z kolekcjonerów. Berliner zgromadził ich jednak mnóstwo i dowiódł ich centralnego miejsca w tematyce pasyjnej.

Obrazy te sprzyjają w szczególny sposób rozumieniu średniowiecznego pojmowania sztuki i rzeczywistości.

Przedstawienia narzędzi męki były obrazami dewocyjnymi, których motywy wybrane zostały według potrzeby religijnej, a nie estetycznej ${ }^{81}$. (...) Cierpiący musi $\mathrm{w}$ określonym szczytowym momencie męki, jeszcze w czasie ziemskiego życia, niejako „przeżyć” wszystko jednocześnie, bo (...) dla tego Cierpiącego rozstrzygająca jest suma cierpienia, nie jego następstwo w realnym czasie $(. . .)^{82}$.

Suma cierpienia nie unieważnia jednak następstwa zdarzeń: całe życie Chrystusa jest rozumiane jako jedna droga przez mękę, z obrzezaniem jako jej pierwszą ważną stacją. Ale zachowanie czasowego następstwa w przedstawieniu nie było istotne. Arma Christi właściwie nigdy nie są uporządkowane chronologicznie, bo chodziło o zaprezentowanie wielości cierpienia: mowa przy tym o zupełnie niewiarygodnych liczbach ${ }^{83 !}$ Dla zrozumienia leżącego u jego podstaw pojęcia sztuki ważne jest jednak, że obrazy i znaki stoją obok siebie, wymieszane, co rzuca osobliwe światło na ówczesne pojęcie obrazu i znaku.

Mówiąc w uproszczeniu, artykuł o Arma Christi jest również historią obrazu dewocyjnego, mimo że Berliner podkreślał wielokrotnie, że nie może takowej zaoferować ${ }^{84}$. Opisuje wszakże przeobrażenia następujące wskutek nowych roszczeń estetycznych od XV wieku, zagrożenia ze strony tendencji racjonalizatorskich czy rozkwit około roku 1600. Myślenie historyczne relatywizuje myślenie idealizujące ${ }^{85}$. Podobnie jak w książce o bożonarodzeniowych szopkach, tak i w przypadku Arma Christi wpro-

81 IX, s. 80. Nadrzędność aspektu religijnego nad estetycznym stanowi wciąż powracające przekonanie Berlinera, m.in. w artykule o Paulusie von Vianen (nr 49, s. 46): „Powaga zadania, jakim było tworzenie obrazów dewocyjnych, skłoniła Vianena do rezygnacji z popisywania się nowatorskimi rozwiązaniami formalnymi czy technicznymi w imię ścisłego przestrzegania istotowych zasad tej gałęzi sztuki religijnej, w której o charakterze rozwiązań formalnych decydują jasność przekazu i koncentracja na tym, co istotne z religijnego punktu widzenia".

82 IX, s. 82. Także obrazy narracyjne mogą prowadzić do jednoczesnego przeżywania następujących po sobie wydarzeń, choćby Rogiera van der Weydena lowańskie Zdjęcie $z$ Krzyża. Zob.: R. Suckale, Rogier van der Weydens Bild der Kreuzabnahme und sein Verhältnis zu Rhetorik und Theologie. Zugleich ein Beitrag zur Erneuereung der Stilkritik, (w:) R. Brandt (red.), Meisterwerke der Malerei, Leipzig 2001, s. 10-44.

83 A. Angenendt i in., Gezählte Frömmigkeit, „Frühmittelalterliche Studien” 29, 1995, s. $1-71$.

${ }^{84} \mathrm{IX}$, s. $40,53,58$ i n.

85 IX, s. 78 i n., 84 i n., 89 i n. o niebezpieczeństwie potraktowania Arma Christi jako motywów dekoracyjnych. 
wadza Berliner przedstawienia - które już przez sam fakt, że zachowały się znacznie lepiej w obszarze sztuki ludowej, wzbudzały nieufność historyków sztuki - na powrót w obszar sztuki wysokiej, pokazując, w jaki sposób zostały z niego stopniowo wyparte. Wiele miejsca poświęca również powstaniu i historii ważnej i specyficznej formy $\mathrm{w}$ obrębie tego typu obrazowego, mianowicie Mszy św. Grzegorza, nie zapomina także o innych obrazach symbolicznych, w tym powstałych w celach mnemonicznych ${ }^{86}$.

A ponieważ forma artystyczna jest tak istotna dla oddziaływania obrazu, skrupulatnej analizie poddawane są kompozycyjne osobliwości i problemy - chociaż nigdy na sposób formalistyczny:

Jako elementy ramujące po bokach szczególnie nadawały się oczywiście podłużne narzędzia jak drabina, kolumna etc. W ten sposób każde narzędzie zajmowało godne siebie miejsce; unikano w ten sposób wszelkiej niejasności w prezentacji poszczególnych motywów i nie zakłócano równowagi w ich generalnym rozdysponowaniu na płaszczyźnie. Ale akcentowanie z mocą formalnej równowagi jedynie w wyjątkowych wypadkach odpowiadało duchowi tematu. Obraz nie miał zasadniczo wywoływać uczucia uspokojenia: niepokój, wstrząs - oto jego właściwy cel $^{87}$.

\section{PODSUMOWANIE}

Rudolf Berliner stworzył w swoich pracach podstawy dla zrozumienia obrazów religijnych, nigdy przy tym nie podporządkowując poszczególnego dzieła ogólnym pojęciom. Przeciwnie: w niezwykłej wprost obfitości rozmaitych przedstawień obrazowych rozpoznał wręcz zasadniczą cechę chrześcijańskiej sztuki Zachodu. Inaczej niż tradycyjne badania ikonograficzne nie rozumiał obrazów bynajmniej jako prostych przekładów tekstów teologicznych. Słowo nie ma pierwszeństwa wobec obrazu. Ikonologia Panofsky'ego, podobnie jak analogiczne sposoby oglądu wypracowane w obszarze humanistyki i historii kultury, nie posiadały dlań mocy obowiązującej w wyjaśnieniu obrazów. Dla ich zrozumienia potrzebna była raczej swoista hermeneutyka, która za punkt wyjścia bierze, z jednej

${ }^{86}$ IX, s. 135, przyp. 398. O Mszy św. Grzegorza: IX, s. 65 i n. Kat. Köln 1982: Die Messe Gregors des Grossen. Vision - Kunst - Realität, hg. v. U. Westfehling. Na temat mnemotechniki zob. pracę F. Yates. The Art of Memory, London 1966, drugie wydanie 1969; J.J. Berns und W. Neuber (red.), Ars memorativa. Zur kulturgeschichtlichen Bedeutung der Gedächtniskunst 1400-1750, Tübingen 1993 (= frühe Neuzeit 15), oraz tych samych autorów, Seelenmaschinen. Gattungstraditionen, Funktionen und Leistungsgrenzen der Mnemotechniken vom späten Mittelalter bis zum Beginn der Moderne, Wien u.a. 2000.

87 IX, s. 91. 
strony, chrześcijańską naukę i widzenie świata, oraz, z drugiej strony, znaczenie obrazu $\mathrm{w}$ obrębie tej religii. W moim przekonaniu historia sztuki nie dysponuje lepszą niż wypracowana przez Berlinera metodą właściwej oceny zarówno specyfiki, jak i obfitości zjawisk obrazowych.

A jednak myśli Berlinera recypowane były w znikomym stopniu. Wpływ na to mieć mogły zarówno nadmiar informacji faktograficznych w jego tekstach, jak i ich pozorne oddalenie od obszaru sztuk pięknych. Że wina nie leżała po stronie autora pokazuje m.in. jego artykuł o $M a$ donnie Sykstyńskiej Rafaela jako religijnym dziele sztuki (XIII), będące studium rozjaśniającym istotę tego arcydzieła, a zarazem stanowiącym okazję do rozwinięcia ogólniejszych przekonań ${ }^{88}$. O niepowodzeniu Berlinera zadecydowało jednak w największym stopniu zjawisko, które określił w 1958 r. jako „leniwe wody ikonografii chrześcijańskiej”, których nie udało mu się „wzburzyć" 89 . Także sterylny intelektualnie i ograniczony artystycznie czas powojenny nie sprzyjał rewizji ani obowiązującego wówczas zideologizowanego obrazu średniowiecza, ani pojęcia sztuki.

Podstawowe przekonanie, że obrazy nie pozwalają przełożyć się całkowicie na słowa, skłaniało go do ostrożności w interpretacjach, do oglądu dzieł raczej z dystansu lub ostrożnego okrążania ich. Implikowało ono także dystans wobec samego siebie i preferowanie niekiedy podejścia eseistycznego. Rozumie się nieomal samo przez się, że ktoś, dla kogo tak ważne były wolność i rozwój osobowości, posiadał również poczucie humoru. Jako potwierdzenie, na zakończenie, tylko jeden przykład ze studium nad rzeźbiarzem w kości słoniowej Thomasem Lenkiem: „[Poczucie humoru] zdaje mi się kulminować $\mathrm{w}$ postaci Wulkana, nadymającego się prawdziwie po męsku - ależ ze mnie facet! A przecież wiadomo, jak poczynała sobie z nim kobieta Wenus i że nie ma powodu, by obawiać się jego młota!"90

Przełożyt Michał Mencfel

88 O tym, że chodziło mu całkowicie o „wielką” sztukę, świadczy entuzjastyczna pochwała obrazów z narzędziami Męki Fra Angelica z cel klasztoru San Marco we Florencji: IX, s. 112. Artykuł XIII traktuje niemal wyłącznie o dziełach Rafaela, Jana van Eycka etc. Wysunięty w XII, s. 91, postulat spisania historii motywu zasłony został po części spełniony; zob.: B.A. Siegel, Der Vorhang der Sixtinischen Madonna. Herkunft und Bedeutung eine Motivs der Marienikonographie, Zürich 1977.

89 XI, s. 177.

${ }^{90} \mathrm{Nr} 25$, s. 28. Zob. także: WK, s. 54: „Ostatnie, czego można by w tym momencie oczekiwać od Marii, to troska o dobrze ułożoną fryzurę, tymczasem narzucony welon i uwolniony spod niego nieskazitelny kosmyk, domagają się oglądu z bliska (...) A jednak kto odważyłby się rozstrzygnąć, czy to nie ta właśnie fryzura ułatwia oglądającym obraz kobietom przeżycie obecności”. Por. także s. 87 i n. 